\title{
Nominal stability over two centuries
}

\author{
Daniel Kaufmann ${ }^{1,2}$ (1)
}

\begin{abstract}
I assess the stability of the monetary environment in Switzerland over the past two centuries. In order to control for transitory measurement errors, in particular in nineteenth century data, I use an unobserved-components stochastic-volatility model to extract the permanent trends from several nominal variables. The descriptive analysis of these trends suggests that the current monetary regime, flexible inflation targeting, provided a relatively stable monetary environment. Although the trends are quite stable for the nineteenth century, the estimates are imprecise. We should therefore be cautious when characterizing metal currency regimes as providing a stable monetary environment. A discussion of the results shows that the apparent success of flexible inflation targeting poses new challenges for the implementation of monetary policy because the trend decline in inflation was associated with a trend decline in nominal interest rates.
\end{abstract}

Keywords: Nominal stability, Price stability, Monetary regimes, Monetary history, Measurement error, Unobserved-components stochastic-volatility model

JEL Classification: $\mathrm{E} 31 ; \mathrm{N1} ; \mathrm{C} 22$

Ultimately, it appears, one can check to see if an economy has a stable monetary background only by looking at macroeconomic indicators such as nominal GDP growth and inflation. On this criterion it appears that modern central bankers have taken Milton Friedman's advice to heart.

Ben S. Bernanke, October 24, 2003

\section{Introduction}

Nowadays, central banks usually announce to stabilize inflation around a numerical target. No modern central bank currently targets the gold price in domestic currency, or issues a commodity money, despite that economic historians report that metal currency regimes provided a high degree of nominal stability and firmly anchored inflation expectations. On the one hand, metal currency regimes may have fallen out of favor because they limit discretionary stabilization policies in favor of long-term price stability (Bordo and Kydland 1996). On the other hand, recent research for the USA suggests that the price

Correspondence: daniel.kaufmann@unine.ch

${ }^{1}$ Institute of Economic Research, University of Neuchâtel, Rue A.-L. Breguet 2, 2000 Neuchâtel, Switzerland

${ }^{2}$ KOF Swiss Economic Institute, ETH Zurich, Leonhardstrasse 21, 8092 Zurich, Switzerland level was less stable and less predictable under the nineteenth century metal currency regimes than under twentieth century fiat currency regimes (see Cogley and Sargent (2015)). In this paper, I assess for Switzerland which monetary regime provided a stable monetary environment over the past two centuries.

The quote by Bernanke (2003) highlights that this assessment should consider various macroeconomic indicators. I therefore compile a novel Swiss data set covering four indicators of nominal stability: consumer prices, wholesale prices, a Gross Domestic Product (GDP) deflator, and nominal GDP per capita. In order to abstract from short-term fluctuations (over which the central bank has less control) and measurement errors (which would distort the analysis), I extract a permanent trend using an extension of the unobserved component-stochastic volatility (UC-SV) model by Stock and Watson (2007), which has recently been proposed by Chan (2013). The extended model allows for a moderately persistent transitory component with time-varying volatility. This property is particularly important when analyzing historical data with possibly persistent measurement errors. In addition, the time-varying volatility allows for the importance of transitory fluctuations to change over time. This captures that transitory measurement errors and supply shocks were likely more important during the nineteenth 
century than under modern fiat currency regimes because of the emergence of modern statistics and changes in the consumption basket, respectively.

The descriptive analysis of these trends suggests that our current monetary regime, flexible inflation targeting, provided a relatively stable monetary environment. Although the point estimates indicate that trend inflation was also relatively stable during the nineteenth century, the uncertainty associated with these estimates is too large to support this result with much confidence. In addition, I show that the decline in trend inflation since the Bretton Woods System can explain a relevant part of the trend decline in nominal interest rates. This poses new challenges for the conduct of monetary policy because of the effective lower bound on nominal interest rates.

The main contribution of this study is to analyze nominal stability on a long historical data set for Switzerland. It is therefore related to studies on the USA and UK that estimate UC-SV models to assess price stability and movements in trend inflation. These studies deal with measurement errors in historical data in several ways. Cogley and Sargent (2015) estimate a univariate UC-SV model on US wholesale price data controlling for persistent measurement error identified from overlapping, methodologically consistent, data sources. Cogley et al. (2015) estimate a model on CPI data for the UK without overlapping data sources; they instead assume that the measurement error variance and persistence changes only when the sources of the historical series differ. Because of data availability, it is not possible to exactly replicate these approaches for Switzerland. Instead, I focus on the permanent component of the nominal indicators after removing a serially correlated transitory component.

The remainder of this paper is structured as follows. The next section defines seven monetary regimes and provides some historical background to highlight their main characteristics. This sets the stage for the empirical analysis, in which I first describe the data. After presenting the model, I discuss the main results against the backdrop of the historical review. The last section discusses the implications for the conduct of Swiss monetary policy and concludes.

\section{Historical background}

Assessing nominal stability over two centuries requires some historical background ${ }^{1}$. The purpose of this review is to (i) define time periods with different monetary regimes, (ii) explain the main objectives of the regimes and how they were integrated in the international monetary system, (iii) show why and when they were abandoned, and (iv) highlight relevant changes in the economic structure unrelated to the monetary regime. The review then allows to interpret the statistical findings against the historical backdrop.
I distinguish between seven distinct regimes since the early nineteenth century: competing currencies, bimetallism, Gold Standard, the World War period, Bretton Woods, monetary targeting, and flexible inflation targeting.

\subsection{Competing currencies (1804-1849)}

During the first half of the nineteenth century, a wide variety of currencies circulated on the territory of the Old Swiss Confederation. This variety was a consequence of the loose association of sovereign cantons (Kantone), associates (Zugewandte Orte), and condominiums (Gemeine Herrschaften) forming the Old Swiss Confederation. Only during the short period of the Helvetic Republic (1798-1803), which was an affiliated republic under French control, some centralized government services were introduced. In particular, the Swiss franc briefly emerged as the single currency (see Maissen (2015), p. 331). However, after the Helvetic Republic collapsed, the cantons took back the prerogative of coinage and partly reissued their old currencies. These domestically issued currencies were often of dubious quality, however. Therefore, transactions were often settled in foreign currency (see Baltensperger (2012), pp. 49-50)2 . Despite a lack of banking regulation, banknotes played a minor role in payment transactions. Private banks and larger cities started to emit banknotes in 1825. Interestingly, these notes were often denominated in foreign currency, which may reflect that for large transactions it has been preferable to use a well-known and widely accepted denomination.

The political environment was fragile, and therefore, the potential temptation to use monetary policy to finance wars substantial. In the Old Swiss Confederation, cantons and cities were engaged in several local conflicts. Examples are the war leading to the secession of the canton of Basel into Basel-city (Stadt) and Basel-rural area (Landschaft), and wars between conservative cantons and liberal rebels. Although these conflicts were local at first, they ultimately led to a war between the Swiss Confederation and an association of conservative cantons in 1847, the so-called Sonderbund War. As the Swiss Confederation quickly won this war, the cantons agreed on a new republican constitution in 1848 (see Maissen (2015), p. 202).

The variety of currencies implied that, unlike today, there was no central bank with a monopoly on minting coins or issuing banknotes. Therefore, a centralized policy with clearly defined objectives did not exist. Some researchers view this episode as a successful example of denationalized competing currencies with a relatively stable purchasing power (see Baltensperger (2012), p. 59-61, and references therein). Hayek (1978) argued that competition among currency issuers prevents inflation because, if they would issue too many banknotes or reduce the 
fineness of metallic coins, the public would simply switch to other currencies with a stable purchasing power.

This positive assessment comes with at least three caveats, however. Baltensperger (2012) emphasizes that issuing banknotes was costly, in particular because of the high level of metal reserves required to establish confidence the purchasing power of the notes. As a consequence, banknotes were rarely used and were seen as imperfect substitutes for coins. In addition, it is important to keep in mind that, besides lacking a common monetary policy, the Old Swiss Confederation was a fragmented economic area without a customs union, and no freedom of establishment. Finally, the local conflicts show that the Old Swiss Confederation was also politically fragmented.

\subsection{Bimetallism (1850-1873)}

The new constitution of 1848 enabled two important changes in the Swiss economic environment: forming a single market and moving towards a more integrated currency union. Elements of the single market included abolishing internal tariffs, unifying external tariffs, generating income for central government services, and guaranteeing freedom of establishment for Christian citizens (see Maissen (2015), p. 204-206).

With the new constitution, the prerogative of coinage moved to the Swiss Confederation and, in 1850, the Swiss franc finally replaced the large number of different coins in circulation. Originally, the Swiss franc was designed as a pure silver currency along the lines of the French franc. One Swiss franc was equivalent to $4.5 \mathrm{~g}$ silver (see Willis (1901), p. 27). In addition to the silver Swiss franc, the government issued token coins; the physical value of token coins was less valuable than their nominal value, which made them particularly useful for smaller transactions (see Baltensperger (2007), p. 32). Because France was on a bimetallic standard, i.e., the government promised to mint a specific amount of gold and silver to coins of a specific value, the Swiss Confederation soon accepted foreign gold coins as legal tender. This step was not entirely voluntary. In the 1850s, the price of silver increased relative to gold. Therefore, it became profitable to melt silver coins, buy gold with the proceedings, and mint gold coins in France. As a consequence, silver vanished from monetary circulation in Switzerland and was replaced by French gold coins (see Baltensperger (2012), p. 83).

In 1865, France, Switzerland, Belgium, Italy, and later on Greece formed the Latin Monetary Union agreeing on the silver content of their currencies. Again, this was a response to market forces revealing unsustainable monetary arrangements (see Eichengreen (2008)). For example, in 1862, Italy reduced the metallic content of silver coins to $83.5 \%$, whereas the silver content of the French franc was still 90\%. Melting French coins and minting them to Italian coins offered therefore a profitable arbitrage opportunity. As a consequence, French coins vanished and were replaced by Italian silver coins. Although France reduced the silver content in 1864, Switzerland reduced the silver content even more. In turn, the Swiss currency tended to drive the other two currencies out of circulation.

From a monetary perspective, the regime is best described as Bimetallism because of the close link to the French franc, because Switzerland soon accepted gold coins as legal tender, and because of its membership in the Latin Monetary Union. The constitution effectively removed competition in coin issuance so that a centralized monetary policy emerged. The main objective of the regime was a single currency that proves useful in payment transactions. Discretionary policies were limited because of the rules of the Latin Monetary Union and because the government had no monopoly on banknote issuance. Commercial banks still had the right to emit their own banknotes (see Baltensperger (2007), p. 111). On the one hand, market forces probably prevented an excessive issuance of banknotes. On the other hand, banknotes were still rarely used in transactions and therefore less useful than silver or token coins.

\subsection{Gold Standard (1874-1906)}

The fate of the Latin Monetary Union was heavily influenced by France. Bimetallism came to an end when France restricted the amount of silver the public was allowed to mint each day in $1873^{3}$. This restriction inflicted with the mechanics of Bimetallism as it limited arbitrage when the relative price of silver and gold was changing. Although the silver minting restrictions were regarded as temporary (see Flandreau (2004), p. 176) the Latin Monetary Union adopted a de facto Gold Standard after $1873^{4}$. France suspended the minting of silver completely in 1876. In 1878, the other countries of the Latin Monetary Union followed.

With the Gold Standard, a truly international monetary system emerged with Great Britain at its center ${ }^{5}$. Each country effectively promised to keep the price of a certain quantity of gold fixed in their currency. Therefore, short-term stabilization policies oriented towards domestic goals were still limited. Still, Friedman (1968) suggests that the main role assigned to monetary policy was "to promote price stability and to preserve the gold standard". The implicit price stability objective, however, was subordinated to the monetary regime. In fact, countries were willing to accept long-lasting deflation to remain on the Gold Standard regime (see, e.g., Burdekin and Siklos (2013)). This subordination acted as a commitment device. Bordo and Kydland (1996) suggest that the commitment to preserve the Gold Standard anchored inflation expectations even during temporary suspensions. 


\subsection{Foundation of the SNB and the World War period (1907-1944)}

During meetings of the members of the Latin Monetary Union, Switzerland repeatedly favored to adopt the Gold Standard and to quickly leave the currency union (see, e.g., Willis (1901), p. 135 and p. 165). Although the foundation of the SNB opened up more leeway for discretionary policies, Switzerland therefore continued to operate in line with the rules of the Gold Standard. In 1907, the Swiss central bank received the monopoly on banknote issuance. Its main objective was a fixed gold price in terms of Swiss francs. This objective was only abandoned during wars and towards the end of the Great Depression. Therefore, a domestic price stability objective was still subordinated to the Gold Standard regime.

The foundation of the SNB and the outbreak of World War 1 (WW1) justify distinguishing the classical Gold Standard from the World War period, even though the Latin Monetary Union officially continued to operate until 1927. With the outbreak of WW1, convertibility was suspended and money in circulation increased strongly in order to finance war-related government spending (see Baltensperger (2012), p. 144-146). Indeed, the Governing Board suggested that "The SNB is the war bank of the state just as much as is the Reichsbank or the Banque de France" (Minutes of the Governing Board quoted in Bordo and James (2007), p. 42). After WW1, the SNB's primary aim was to establish the pre-war gold-parity and, as of December 1929, the SNB reenacted convertibility.

Researchers date the end of the classical Gold Standard to the outbreak of WW1 because all major countries suspended convertibility. Afterwards, the international monetary regime during the inter-war years differed from the classical Gold Standard because central banks held their reserves partly in gold and partly in foreign currency. However, there is evidence that a Gold Standard "mentality" still shaped policy decisions as well as the public's expectations. Eichengreen and Temin (2000) and Straumann (2010) suggest that, during the Great Depression, policy makers justified their actions with arguments valid under the classical Gold Standard, although they would have had more leeway to conduct a more expansionary monetary policy. This was also true for the SNB, determined to hold on to the Gold Standard until 1936 even though this has exacerbated and prolonged the crisis (Zurlinden 2003; Rosenkranz et al. 2014) ${ }^{6}$.

\subsection{Bretton Woods (1945-1973)}

After World War 2 (WW2), Switzerland joined the Bretton Woods System. Countries fixed their exchange rate vis-à-vis the US dollar; at the same time, the USA fixed the US dollar price of gold. Although Switzerland was not an official member, it decided unilaterally to fix its exchange rate to the US dollar and therefore implicitly participated in the system. Similar as under the Gold Standard, the main objective was a fixed exchange rate and price stability was a subordinated goal.

The Bretton Woods System underwent significant changes during this period. Before 1951, the USA kept the interest rate pegged for most of the time and therefore could not pursue an independent monetary policy (see, e.g., D’Agostino and Surico (2012)). Afterwards, changes in US monetary policy had limited international spillovers because capital controls were in place. Eichengreen (2008), p. 112, suggests that the Bretton Woods System has come into full operation only by January 1959, when the major currencies became fully convertible for currentaccount transactions.

The ongoing removal of capital controls led to capital inflows into Switzerland because the Swiss franc was undervalued at the prevailing fixed nominal exchange rate (Bernholz (2007), p. 111-112 and 147). Under a flexible exchange rate regime, these capital inflows would tend to appreciate the Swiss currency helping to restore external balance. Under the Bretton Woods System, however, the SNB was determined to keep the nominal exchange rate fixed $^{7}$. This implied that Switzerland either had to resort to capital controls or counter the capital inflows with an expansion of the money stock. Without resorting to substantial capital controls the SNB had to accept a rising price level for the Swiss franc to appreciate in real terms ${ }^{8}$. Towards the end of the Bretton Woods System, Switzerland adjusted the exchange rate peg two times, in 1971 and 1972. In January 1973, the SNB decided to let the Swiss franc float freely. All three adjustments led to a substantial appreciation of the Swiss currency.

According to Baltensperger (2012), p. 215, letting the Swiss franc float was not entirely voluntary. The SNB and the Swiss government judged the interventions required to maintain the peg as unsustainable, against the backdrop of massive speculative capital flows. Although inflation increased steadily already during the 1960s, the willingness to keep the exchange rate fixed was stronger suggesting that an implicit price stability objective was subordinated to an exchange rate stability objective. The exchange rate peg was adjustable to correct a "fundamental disequlibrium" (see, e.g., Obstfeld (1993)); this option was rarely exercised in practice, however (see Eichengreen (2008), p. 91). This subordination is also presaged by Bernholz (2007), p. 110-111. He identifies two dominant themes for the SNB under the Bretton Woods System: First, the SNB wanted to keep a fixed price for gold in Swiss francs; this goal was widely shared by the government, politicians, and academics. Second, it wanted to allow the money supply to rise only as much as the growth of the economy, in order to keep inflation in check, as far as possible. 


\subsection{Monetary targeting (1974-1999)}

With a floating exchange rate, the SNB obtained the possibility to conduct an independent monetary policy geared towards domestic goals ${ }^{9}$. Starting in 1974 the SNB developed a strategy for managing the money supply. The annual monetary growth targets were not an end but an intermediate target to maintain price stability. Therefore, this was the first time price stability emerged as the main objective. Jordan et al. (2010) suggest that, implicitly, an annual CPI inflation objective of roughly $1 \%$ was consistent with the SNB's communicated monetary targets. An explicitly announced inflation target, however, did not exist at the time.

Although the Swiss franc was floating, currency fluctuations were still taken into account in policy decisions. In October 1978, the SNB set a minimum exchange rate against the German Mark. There is evidence that maintaining price stability was not the main reason for introducing this policy. For one, the lowest annual CPI inflation rate (in 1978) amounted to $1.0 \%$, in line with the SNB's implicit policy objective. Before and after, CPI inflation was higher than $2 \%$. For another, Bernholz (2007), p. 179-181, suggests that worries about the export industry and political pressure have played a role for introducing the minimum exchange rate.

As for many other historical episodes, monetary targeting was abandoned in response to a changing economic environment. Jordan and Peytrignet (2007) suggest that the demand for base money had become too unstable to serve as an indicator of the stance of monetary policy ${ }^{10}$. However, the monetary targeting framework was gradually adapted rather than suddenly abandoned. Because the SNB regularly missed its annual monetary growth objectives it started to announce a medium-term expansion path starting in 1991. Baltensperger (2012) emphasizes that, for pursuing its short-term objectives, the SNB increasingly paid attention to a number of indicators, such as interest rates, the exchange rate and the business cycle. This paved the way for abandoning monetary targeting and led to a gradual shift towards flexible inflation targeting.

\subsection{Flexible inflation targeting (since 2000)}

In December 1999, the SNB officially announced its new monetary policy strategy: a flexible form of inflation targeting ${ }^{11}$. The main differences to monetary targeting are reflected in the communication of objectives and decisions, as well as, the choice of the operational target. The new monetary policy strategy rests on three main principles (see Jordan et al. (2010)). Firstly, the SNB announced an explicit definition of price stability of an annual CPI inflation rate below $2 \%$ in the medium term. Deflation, which the SNB defines as a protracted decline in the price level, is also inconsistent with its definition of price stability. It is therefore common to assume that the mediumterm inflation target of the SNB is a range of $0-2 \%$. The positive target range is justified by unmeasured quality changes causing the official statistic to overstate CPI inflation (Swiss National Bank 2015) ${ }^{12}$. Therefore, the SNB's target range for actual inflation is somewhat lower than $0-2 \%$. Secondly, the SNB publishes an inflation forecast over 3 years, conditional on an unchanged $3 \mathrm{M}$ Libor, as the main communication tool of (future) policy decisions. Thirdly, it sets a range for the $3 \mathrm{M}$ Libor as an operational target.

In the wake of the Global Financial Crisis (GFC), unconventional policy measures complemented the flexible inflation targeting framework. As the $3 \mathrm{M}$ Libor fell to close to $0 \%$ in early 2009, the Swiss franc came under substantial appreciation pressure. Therefore, the SNB conducted regular interventions in the foreign exchange market in order to limit the risk of deflation (see, e.g., Swiss National Bank (2009)). As the Swiss franc appreciated to unprecedented highs in Summer 2011, the most prominent unconventional measure was the announcement of a minimum exchange rate against the euro as a complementary operational target ${ }^{13}$. Moreover, to defend the minimum exchange rate, the SNB announced to introduce negative interest rates on sight deposits in December 2014 and moved the target range for the $3 \mathrm{M}$ Libor into negative territory. In January 2015, facing potentially large interventions because of an large-scale asset purchase program by the European Central Bank, the minimum exchange rate was abandoned and the target range for the $3 \mathrm{M}$ Libor was lowered further. Meanwhile, however, the SNB emphasized that it will continue to in tervene in the foreign exchange market if the Swiss franc were to appreciate further.

We have seen that, under flexible inflation targeting, the SNB conducted non-conventional policies similar as under monetary targeting. One important difference to earlier interventions is that the measures were taken in order to prevent deflation and thus pursue an explicitly announced price stability objective (see, e.g., Swiss National Bank (2009)). The determination is reflected in the substantial non-conventional policy actions taken since the GFC. But also, the price stability objective is reflected in a speech by Jordan (2009) discussing how the SNB plans to soak up the liquidity created by the exchange rate interventions in order to prevent an excessive rise in inflation. Therefore, flexible inflation targeting is the first regime with an explicit numerical price stability objective ordered first in the hierarchy of goals.

\section{Data}

This section presents four indicators to assess nominal stability over the past two centuries. As the quote by 
Bernanke (2003) at the beginning of this paper suggests, a stable monetary environment should be reflected in stable aggregate inflation and nominal GDP growth. However, there is no general agreement on the most appropriate measure of nominal stability, and various indicators are likely to be informative. Moreover, each time series is prone to measurement error, in particular for retrospectively constructed historical statistics. Therefore, this analysis considers a range of indicators. Available historical statistics for Switzerland allow to construct spliced measures for consumer prices (CPI), wholesale prices (WPI), a GDP deflator (DEFL), and nominal GDP per capita (NGDP).

CPI inflation is an obvious candidate because, since the introduction of the new monetary policy framework in 1999, the SNB bases its price stability definition on this statistic. Frankel (2012b) suggests that a central bank of a small open economy should instead stabilize an index of producer prices because it includes export commodities. The central bank thus avoids to respond to terms of trade shocks over which it has no control. As an alternative, we can also analyze a GDP deflator that additionally includes consumer prices but excludes prices of imported goods and services. Finally, researchers have suggested that the central bank should target the growth rate or level of nominal GDP. Although this idea is not new, it was already proposed by Meade (1978), it regained attention in the wake of the GFC (see, e.g., Frankel (2012a), Sumner (2014), and references therein). This measure of nominal stability takes into account fluctuations in inflation, as well as, the business cycle. It can be therefore interpreted as a summary measure of a dual objective giving similar weight to inflation and real activity stabilization. In addition, this indicator takes into account changes in productivity ${ }^{14}$. Therefore, the analysis is not confounded by what Bordo and Filardo (2005) term "good" deflations ${ }^{15}$. This describes a situation where prices decline because of advances in productivity. While the central bank would not respond to such price declines when pursuing a nominal GDP target, it would respond with a more expansionary monetary policy when targeting price inflation.

\subsection{Sources}

All indicators are of annual frequency and end in 2017 (2016 for per capita nominal GDP). The CPI is available for the entire nineteenth century and the WPI starts in $1804^{16}$. Nominal and real GDP, and therefore the GDP deflator, start in 1851. The historical data for the nineteenth century stem from the historical database of the Swiss Federal Statistical Office (SFSO), Historical Statistics of Switzerland Online (HSSO) of the University of Zurich, and Studer and Schuppli (2008). I splice various sources after calculating log-differences. Where overlaps of different sources exist, I compute the correlation between the two series to check whether linking them makes sense.

Studer and Schuppli (2008) provide a retrospectively estimated CPI for the entire nineteenth century until 1914. It includes prices for a fixed basket of 12 goods sold in Zurich until 1890 and a fixed consumer goods basket for German-speaking Switzerland thereafter. From 1914 onward, I splice the series with the official CPI from the (SFSO 2015c). HSSO (2015), Table H39, also comprises a CPI from 1804 to 2003 which is compiled from various data sources. Fortunately, the correlation between the two series is indeed high (0.85). I still favored the measure by Studer and Schuppli (2008) because, between 1835 and 1851, the HSSO (2015) CPI estimate is largely based on WPI data ${ }^{17}$.

The WPI stems from HSSO (2015), Table H39, and covers 1804-2003. This measure already links retrospectively calculated and official statistics in 1914. I link the series with the official WPI (Preisindex des Gesamtangebots) from the (SFSO 2015c). To the best of my knowledge, no overlap of historical estimates and modern statistics exists.

Nominal GDP data starts in 1851. I splice three different sources before 1980 (HSSO (2015) Tables Q1a, Q17a, Q6a). After 1980, the official annual nominal GDP series stems from the State Secretariat for Economic Affairs (SECO 2015). The correlation between overlapping data sources is larger than 0.9 . The only exception is the overlap between the historical series and the official series from the SECO, where the correlation amounts only to 0.76 . To obtain a historical measure for nominal GDP per capita, I divide the spliced series by the annual permanent resident population of Switzerland starting in 1861 (SFSO 2015a). The resulting series is linked with an NGDP per capita series available from 1851 to 1861 (see HSSO (2015) Table Q1a). After 1990, I use the official series from the SFSO (2015b), which ends in 2016. Correlations on overlapping samples between the three data sources are larger than 0.95 . From the same sources, I constructed a measure of real GDP and then calculated the implicit GDP deflator.

To discuss the consequences of various nominal regimes, I also construct an annual series of government bond yields from 1899-2017. The historical data stem from the Swiss National Bank (2007a) and the modern data from the SNB's website ${ }^{18}$. The first series is an average of outstanding Swiss railway bonds starting in 1899. The Swiss National Bank (2007a) suggests that railway bonds were representative of the Swiss capital market in the early twentieth century. I splice this series with an average yield of railway and Confederation bonds in 1924 . The residual maturity of the bonds included in this average was at least 5 years. I splice this series with a 10 -year constant maturity Confederation bond yield in $1988^{19}$. 


\subsection{Descriptive statistics}

Figure 1 shows the levels of the four nominal indicators in logarithms. The seven monetary regimes are represented by shaded and unshaded areas. The indicators display different long-term trends. The CPI and GDP deflator rise less, on average, than nominal GDP. This is related to the fact that nominal income rises not only because of increases in prices, but also, productivity. The WPI rises less than the other two price indices, in particular, since official price data is available (in 1914). One reason could be that services prices included in the CPI and GDP deflator rise more strongly than goods prices.

Abstracting from the long-term trends, the CPI, GDP deflator, and the WPI display periods with substantial deflation. For example, after Switzerland adopted a de facto Gold Standard in 1874 all price indices fell substantially. Meanwhile, the decline in nominal GDP was less pronounced. This was a period with substantial increases in productivity but a relatively fixed world-wide gold stock for monetary use. As a consequence, the decline in prices was caused by productivity gains and was therefore less harmful than, for example, deflationary episodes during the Great Depression (see, e.g., Beckworth (2007)). By contrast, and in line with findings in other countries (see, e.g., Bernholz (2003), p. 3), the largest and most persistent increases in all nominal variables occurred during the twentieth century fiat money regimes. The increase was less pronounced, however, under flexible inflation targeting than during Bretton Woods or monetary targeting.

To get a first impression whether the regimes provided a stable monetary environment, we can compute the average growth rate and volatility of the indicators (see Table 1). Metallic regimes are often considered as providing a stable monetary environment. The descriptive statistics paint a more nuanced picture. Focusing on the CPI, we observe secular deflation under competing currencies and the Gold Standard, and relatively high inflation under Bimetallism. Since the foundation of the SNB, secular inflation became the norm. During the world war period, under Bretton Woods, as well as under monetary targeting, CPI inflation was on average higher than $2 \%$. Only with flexible inflation targeting we observe a low and stable average inflation rate. Recall that the SNB currently defines price stability as an annual increase in CPI inflation between 0 and $2 \%$, which was also in line with the implicit price stability objective under monetary targeting. CPI inflation was on average consistent with this target only under flexible inflation targeting. During the other monetary regimes, the average inflation rate was either higher (bimetallism, Bretton Woods, monetary targeting) or lower (competing currencies, Gold Standard). The average inflation rate measured by the GDP deflator, but also nominal GDP growth, displays similar patterns. The main difference is that nominal GDP growth is on average higher because of positive productivity growth.

Average growth rates over long sample periods possibly conceal persistent episodes with high inflation which are offset by deflationary episodes. If the low average rate of inflation stems from offsetting periods with inflation and deflation, we would expect that inflation is rather volatile pointing to an unstable monetary environment. Table 1 shows that inflation according to all price indices was volatile under competing currencies and bimetallism. Under the Gold Standard, the volatility generally declined.

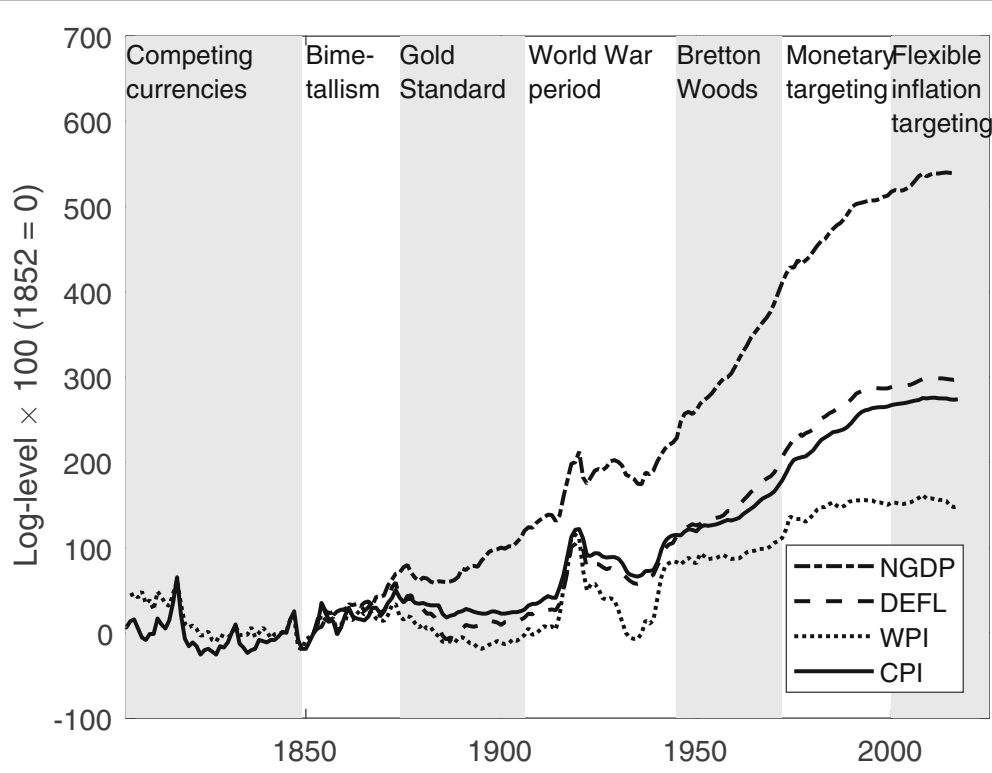

Fig. 1 Data. All series are shown in log-levels, multiplied by 100, and indexed to zero in 1852. The shaded and unshaded areas represent various monetary regimes 
Table 1 Descriptive statistics

\begin{tabular}{|c|c|c|c|c|c|c|c|c|}
\hline & \multicolumn{2}{|c|}{$\mathrm{CPI}$} & \multicolumn{2}{|c|}{ WPI } & \multicolumn{2}{|c|}{ DEFL } & \multicolumn{2}{|c|}{ NGDP } \\
\hline & Mean & Std. & Mean & Std. & Mean & Std. & Mean & Std. \\
\hline 1804-1849: Competing currencies & -0.8 & 13.3 & -1.4 & 10.7 & & & & \\
\hline 1850-1873: Bimetallism & 2.9 & 9.3 & 2.2 & 6.6 & 3.2 & 11.6 & 3.9 & 5.2 \\
\hline 1874-1906: Gold Standard & -0.7 & 3.1 & -1.1 & 4.3 & -1.3 & 5.6 & 1.5 & 4.0 \\
\hline 1907-1944: World War period & 2.3 & 8.1 & 2.3 & 14.5 & 2.3 & 8.5 & 2.7 & 9.1 \\
\hline 1945-1973: Bretton Woods & 2.3 & 2.1 & 1.0 & 3.3 & 3.6 & 2.7 & 6.7 & 3.9 \\
\hline 1974-1999: Monetary targeting & 3.2 & 2.5 & 1.4 & 4.1 & 3.0 & 3.2 & 3.8 & 3.2 \\
\hline 2000-2017: Inflation targeting & 0.5 & 0.9 & -0.1 & 2.3 & 0.6 & 0.9 & 1.6 & 2.4 \\
\hline
\end{tabular}

Mean and standard deviation of log-changes in percent

After the World War period, the volatility declined for all indicators and attained an all-time low under flexible inflation targeting. A similar pattern emerges for nominal GDP growth.

The high volatility of the indicators under bimetallism and competing currencies also implies that the means are imprecisely estimated. Therefore, if we ask whether these regimes were associated with a low or high mean, we cannot reach a conclusion with much confidence.

In addition, the lower volatility after the World War period can have different causes. Bordo and Filardo (2005) suggest that volatile supply shocks make up for a larger share of the variation during the early sample period due to changes in the consumption basket. A nineteenth century consumption basket comprised a higher share of food products with relatively volatile prices. But also, the lower volatility may stem from better quality of the official statistics emerging during the twentieth century (see, e.g., Romer (1986a, b); Allen (1992); Kaufmann (2017) for the USA). Finally, the declining volatility may reflect a more stable monetary environment. While supply shocks and measurement errors are likely to affect the shortrun dynamics of the indicators, a well-managed monetary regime is likely to lead to a more stable trend.

To disentangle transitory from trend fluctuations, as well as estimate the uncertainty associated with the analysis, I propose to use a statistical model in the next section.

\section{Method}

To measure the stability of the monetary environment using historical data of varying quality, I decompose the indicators into a permanent and a transitory component. The permanent component represents the best long-run forecast of the corresponding indicator given the current state of information, following Beveridge and Nelson (1981). It is also common to interpret the permanent component as a measure of trend inflation (see Ascari and Sbordone (2014) and references therein). I estimate the trend using the univariate unobserved componentstochastic volatility (UC-SV) model by Chan (2013). The model is a generalization of the popular UC-SV model by Stock and Watson (2007) allowing for a persistent transitory component.

\subsection{Model}

Assume that the log-change of the indicator of nominal stability $\left(y_{t}\right)$ can be decomposed into a permanent component and a moving-average (MA) component $\left(u_{t}\right)$ :

$$
y_{t}=\tau_{t}+u_{t} .
$$

The permanent component follows a random walk process:

$$
\tau_{t}=\tau_{t-1}+\varepsilon_{t}^{\tau} .
$$

The MA component is assumed to be of order one:

$$
u_{t}=\varepsilon_{t}^{u}+\psi \varepsilon_{t-1}^{u},
$$

where we restrict $|\psi|<1$ for identification.

The interpretation of the model in our application is that transitory movements in inflation or nominal GDP growth-stemming from non-systematic measurement errors, supply shocks, or short-lived recessions-are captured by $u_{t}$. Meanwhile, the long-term trend in inflation or nominal GDP growth, over which the central bank likely has more control, is captured by the permanent component ${ }^{20}$.

The relevance of short-term fluctuations, but also the volatility of the permanent component, has likely changed over time. Therefore, we allow the variance of the permanent shocks $\left(\varepsilon_{t}^{\tau}\right)$ and transitory shocks $\left(\varepsilon_{t}^{u}\right)$ to change over time. Following Chan (2013), I assume that the permanent and transitory shocks have stochastic volatility. Formally, we have that $\varepsilon_{t}^{\tau} \sim$ i.i.d.N $\left(0, e^{g_{t}}\right)$ with:

$$
g_{t}=\mu_{g}+\phi_{g}\left(g_{t-1}-\mu_{g}\right)+\varepsilon_{t}^{g}, \quad \varepsilon_{t}^{g} \sim N\left(0, \sigma_{g}^{2}\right),
$$

and $\varepsilon_{t}^{u} \sim$ i.i.d.N $\left(0, e^{h_{t}}\right)$ with:

$$
h_{t}=\mu_{h}+\phi_{h}\left(h_{t-1}-\mu_{h}\right)+\varepsilon_{t}^{h}, \varepsilon_{t}^{h} \sim N\left(0, \sigma_{h}^{2}\right) \text {, }
$$

where we assume that $\left|\phi_{g}\right|<1,\left|\phi_{h}\right|<1$.

The model departs in various dimensions from existing research on trend inflation. Kugler (1999) finds that the Swiss price level was trend stationary from 1973 to 1995. 
For most of the remaining sample period, Switzerland was linked to the international monetary system through fixed exchange rates, however. Therefore, I prefer a specification with a random walk component in inflation as Cogley and Sargent (2015) for the USA and Cogley et al. (2015) for the UK. In addition, the current monetary regime is best described as flexible inflation targeting rather than price-level targeting ${ }^{21}$.

Stock and Watson (2007) propose a variant of the model without the MA component. In the present application, however, it is desirable to allow for the possibility that transitory fluctuations are at least somewhat persistent. On the one hand, measurement errors in the nineteenth century inflation are somewhat persistent (Cogley and Sargent 2015). On the other hand, there is evidence that the transitory component of inflation is somewhat persistent under fiat currency regimes (Cogley et al. 2010). I do not aim to separately identify the two sources of persistence, however.

This is done by Cogley and Sargent (2015), who control for persistent measurement error exploiting overlapping, methodologically consistent, data sources of US inflation. The advantage of their approach is that they can estimate a permanent as well as a transitory component controlling for measurement error. In addition, they allow the persistence and volatility of the measurement error process to change discretely when retrospective estimates are spliced with modern data. However, they assume that the transitory component of well-measured inflation is serially uncorrelated.

Without overlapping sources of historical data, Cogley et al. (2015) estimate the persistence and variance of measurement errors in historical data using two assumptions. In their model, the parameters change discretely whenever the series is spliced with another source. This ignores that data quality can change substantially within a particular segment of spliced historical CPIs because the quality of the underlying data sources changes (see Kaufmann $(2017))^{22}$.

The model in this paper allows for a persistent transitory component not only during the nineteenth century but also during fiat currency regimes. Unlike Cogley et al. 2015, I allow the variance of the transitory component to continuously change over time. This component is most likely driven by measurement errors during the nineteenth century and by well-measured inflation during fiat currency regimes. This comes at the cost, however, that the persistence is assumed to be constant over time.

\subsection{Estimation}

The model is estimated using Bayesian methods. Chan (2013) develops an MCMC sampler exploiting the special structure of the problem to efficiently evaluate the likelihood function ${ }^{23}$. For most parameters, I assume relatively non-informative priors (see Appendix). Only for the autoregressive parameters in the stochastic volatility equations I put an informative prior on the high persistence region. In addition, although the prior on $\sigma_{g}^{2}$ is not very informative, the posterior is almost identical: the data contain hardly any information on this variance (see Appendix). I therefore provide some robustness tests for alternative prior assumptions.

The analysis is based on 150,000 iterations of the MCMC algorithm where the first 100,000 iterations are discarded for convergence. I provide plots of the Markov chain for several key parameters to check convergence (see Appendix). They suggest that the algorithm has converged.

To check whether it is necessary to allow for a persistent transitory component, Table 2 provides posterior moments for the MA parameter $(\psi)$. We see that the point estimate, the posterior mean, ranges from 0.25 to 0.44 depending on the indicator. The posterior standard deviation shows that the parameter is precisely estimated for all indicators. This suggests that the data indeed favor a specification with a MA part. This is confirmed by the high posterior probability that the parameter is positive. Finally, the last line gives the Bayes factor in favor of the model with the MA component against the variant without the MA component proposed by Stock and Watson (2007). The results suggest that there is strong evidence in favor of the specification with the MA component ${ }^{24}$.

\section{Results}

I first discuss the estimated trends in a descriptive way before assessing the regimes in terms of a definition of nominal stability. Finally, I show that variation in trend inflation explains a relevant part of the trend decline in nominal interest rates during the 20th century.

Figure 2 shows the posterior mean of the permanent component jointly with 5 th and 95th percentiles. The dashed line represent the underlying data. For CPI inflation, we observe a stable trend for most of the nineteenth century. In line with the descriptive statistics, trend inflation was slightly positive during bimetallism and essentially zero during competing currencies and the Gold

Table 2 Model specification

\begin{tabular}{lllll}
\hline & CPI & WPI & DEFL & NGDP \\
\hline$E[\psi \mid \mathbf{y}]$ & 0.44 & 0.25 & 0.31 & 0.27 \\
$\sqrt{\operatorname{var}[\psi \mid \mathbf{y}]}$ & 0.06 & 0.08 & 0.08 & 0.08 \\
$P[\psi>0 \mid \mathbf{y}]$ & 1.00 & 1.00 & 1.00 & 1.00 \\
Bayes factor & $2.08 \times 10^{106}$ & 11.98 & 93.34 & 17.57 \\
\hline
\end{tabular}

The table gives the posterior mean, standard deviation, and the posterior probability that the MA coefficient is larger than zero. The last line gives the Bayes factor in favor of the model with the MA component against the variant without the MA component (see Chan (2013) for computational details). To calculate the Bayes factor, the posterior density was evaluated using a kernel density estimator 

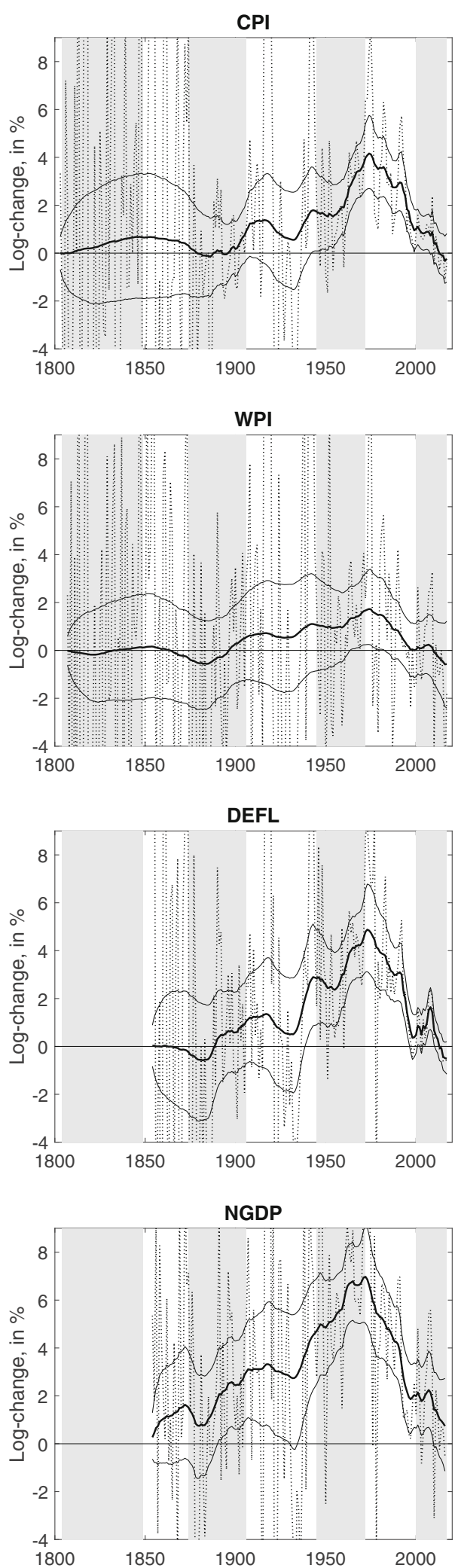

Fig. 2 Permanent component. Estimated permanent component (mean, 5th percentile, 95th percentile) and actual data (dashed line). The shaded and unshaded areas represent various monetary regimes
Standard. For competing currencies, this result comes with the caveat that the economic integration was very limited and that the price index based on Zurich data may not be representative for price developments in other areas of the fragmented Old Swiss Confederation. Taking the point estimates at face value, we would conclude that bimetallism was less deflationary than the Gold Standard, supporting the favorable characterization by Flandreau (2004). For most of the nineteenth century, however, the estimates are imprecise. For example, the difference between the 95th and 5th percentile amounts to more than $5 \mathrm{pp}$ in the $1850 \mathrm{~s}$. The high volatility of the data hampers to obtain a precise estimate, and we should be careful to interpret this period as featuring a stable monetary environment. Put differently, the data do not allow to identify with much confidence whether trend inflation amounted to $-2 \%$ or $+2 \%$ during this period.

The estimates become somewhat more precise during the Gold Standard period, where the inflation trend fell to essentially zero. This decline can be explained against the backdrop of international developments. In the early 1870s, Germany and other European countries adopted the Gold Standard and liquidated their silver currency reserves. The result was a strong deflation in Great Britain and other countries because the increased global demand for monetary gold was not matched by an equal increase in supply (Eichengreen (2008), p. 17).

After the Gold Standard period, however, the inflation trend increases before falling slightly during the inter-war period. This lines up well with the fact that Switzerland suspended convertibility with the outbreak of WW1. Afterwards, deflationary pressures emanated from establishing the pre-war gold-parity as well devaluing relatively late during the Great Depression. Nevertheless, the model attributes most of the fluctuations during the inter-war period to the transitory component. This is consistent with Bordo and Kydland (1996) and Hoffmann and Woitek (2011) suggesting that the Gold Standard anchored expectations even during supposedly transitory suspensions. Hoffmann and Woitek (2011) analyze the economic dynamics for a set of countries that, similar to Switzerland, devalued during WW1 and repegged their currencies at the previous parity during the inter-war period. Their model explains current account dynamics well under the classical Gold Standard and the inter-war period, suggesting that the expectation formation mechanism has remained largely unchanged. This is also supported by our estimates for the Great Depression, when Switzerland refrained from devaluing its currency longer than other countries. Despite the relatively high estimation uncertainty, it is remarkable that the trend did not decline more strongly given the deflationary forces during the Great Depression. 
During WW2, the inflation trend increased again towards $2 \%$ and remained at this level for the first part of the Bretton Woods regime. This suggests that the fixed exchange rate regime was associated with a high degree of monetary stability only as long as capital controls were in place and monetary policy in the USA was not too expansionary. During the second half, when capital controls were increasingly lifted, the trend surpasses $2 \%$ and attains about $4 \%$ towards the end of the Bretton Woods System. This suggests that, even if there was an implicit price stability objective, the SNB was willing to allow large and persistent deviations before adjusting the exchange rate peg. As a consequence, the expansionary monetary policy in the USA pushed the inflation trend higher in Switzerland as well.

This episode highlights that monetary regimes often fail when the economic environment reveals its inherent weaknesses. The fixed exchange rate regime was only abandoned when the inflation trend rose to an unprecedented high, which was unacceptable to policy makers. The reason was a change in the economic environment under which the regime stopped working well: a too expansionary monetary policy in the country issuing the reserve currency and increasingly liberalized capital markets. Afterwards, under monetary targeting, we observe a gradual decline when the SNB had more leeway to conduct an independent monetary policy.

Recall that, under monetary targeting, the SNB's implicit inflation target was $1 \%$. We see, however, that the inflation trend remained elevated throughout the 1980s. Trend inflation then declined during the 1990s and remained low and stable during flexible inflation targeting. Importantly, the estimates based on modern data are much more precise. Therefore, we can say with some confidence that flexible inflation targeting was associated with the lowest inflation trend among the modern fiat money regimes. Having said that, the inflation trend already declined to a low level when monetary targeting was still in place. Therefore, the new regime was probably not the main cause why inflation declined in the first place. What we can say, however, is that the regime probably helped that inflation remained low thereafter and did not decline more during the GFC.

The other indicators qualitatively confirm this assessment. We observe relatively imprecise estimates during the metal currency regimes of the nineteenth century. If anything, however, all indicators point to a falling trend at the beginning of the 1870s. During WW2, the trend rose to a higher level and continued to increase towards the end of the Bretton Woods System. Finally, we observe a falling trend towards the end of monetary targeting, and a historically low trend under our current monetary regime. The pattern is less visible for the WPI than for the GDP deflator and nominal GDP. This could be related to the fact that a WPI is strongly influenced by volatile supply shocks and therefore driven to a smaller extent by the permanent component.

Another way to assess nominal stability is to evaluate whether the inflation trend remained within the SNB's current medium-term objective for CPI inflation (0-2\%). This allows to numerically assess whether a regime provided a stable monetary environment. In addition, this evaluation is guided by the view that a central bank should stabilize a magnitude it actually can control in the long term $^{25}$. Finally, it is motivated by the current consensus that firmly anchored inflation expectations are a necessary condition for efficient short-term stabilization policies. I investigate other numerical definitions of price stability in the robustness section.

Recall that the permanent component is a measure of the best long-run forecast of inflation given all available information. Therefore, it is a measure where inflation will settle in the long-run once transitory shocks dissipate. To show whether the monetary regimes performed well, I calculate the posterior probability that the permanent component remains in the target range ${ }^{26}$. The posterior probability of nominal stability declines with higher estimation uncertainty, all else equal: when the trend is less precisely estimated more mass of the posterior distribution lies outside of the stability range. Therefore, the probability of nominal stability already takes into account how confident we are that the monetary environment was stable given the relatively poor quality of the data for the nineteenth century.

Table 3 shows the results. Focusing on the CPI inflation trend, there was about a $50 \%$ chance that a metal currency regime provided nominal stability. For the fiat currency regimes, the evidence is mixed. The Bretton Woods System performed worse. Under monetary targeting, the probability of nominal stability even fell to a low of 20\%. As (Baltensperger 2012) and (Bernholz 2007) emphasize, the stability provided by the monetary targeting regime with flexible exchange rates may still have been a success in relative terms, against the backdrop of high inflation rates observed internationally. Finally, the table confirms the visual impression of the permanent component that our current regime performed remarkably well. No other regime was associated with a probability of nominal stability of $76 \%$.

It is also interesting to investigate why the regimes failed. The model can be used to judge whether a monetary regime showed an inflationary or deflationary tendency by looking at the posterior probability that trend inflation fell short of or exceeded the nominal stability range (panels b and c). Focusing on the CPI, the fixed exchange rate regime of Bretton Woods and monetary targeting show an elevated probability of an excessively high inflation trend. Meanwhile, the metal currency regimes 
Table 3 Probability of nominal stability

\begin{tabular}{|c|c|c|c|c|}
\hline & $\mathrm{CPI}$ & WPI & DEFL & NGDP \\
\hline \multicolumn{5}{|l|}{ (a) Nominal stability: $P\left[\underline{\tau}<\tau_{t}<\bar{\tau} \mid \mathbf{y}\right]$} \\
\hline 1804-1849: Competing currencies & 0.48 & 0.65 & & \\
\hline 1850-1873: Bimetallism & 0.50 & 0.60 & 0.44 & 0.31 \\
\hline 1874-1906: Gold Standard & 0.55 & 0.62 & 0.49 & 0.49 \\
\hline 1907-1944: World War period & 0.63 & 0.64 & 0.49 & 0.43 \\
\hline 1945-1973: Bretton Woods & 0.40 & 0.65 & 0.15 & 0.04 \\
\hline 1974-1999: Monetary targeting & 0.20 & 0.72 & 0.21 & 0.27 \\
\hline 2000-2017: Inflation targeting & 0.76 & 0.73 & 0.70 & 0.53 \\
\hline \multicolumn{5}{|l|}{ (b) Overshooting: $P\left[\tau_{t}>\bar{\tau} \mid \mathbf{y}\right]$} \\
\hline 1804-1849: Competing currencies & 0.12 & 0.07 & & \\
\hline 1850-1873: Bimetallism & 0.15 & 0.09 & 0.06 & 0.04 \\
\hline 1874-1906: Gold Standard & 0.02 & 0.05 & 0.08 & 0.11 \\
\hline 1907-1944: World War period & 0.21 & 0.22 & 0.31 & 0.45 \\
\hline 1945-1973: Bretton Woods & 0.59 & 0.31 & 0.85 & 0.96 \\
\hline 1974-1999: Monetary targeting & 0.79 & 0.24 & 0.77 & 0.68 \\
\hline 2000-2017: Inflation targeting & 0.01 & 0.02 & 0.04 & 0.03 \\
\hline \multicolumn{5}{|l|}{ (c) Undershooting: $P\left[\tau_{t}<\underline{\tau} \mid \mathbf{y}\right]$} \\
\hline 1804-1849: Competing currencies & 0.41 & 0.28 & & \\
\hline 1850-1873: Bimetallism & 0.35 & 0.31 & 0.51 & 0.65 \\
\hline 1874-1906: Gold Standard & 0.43 & 0.33 & 0.43 & 0.41 \\
\hline 1907-1944: World War period & 0.16 & 0.15 & 0.20 & 0.12 \\
\hline 1945-1973: Bretton Woods & 0.01 & 0.04 & 0.00 & 0.00 \\
\hline 1974-1999: Monetary targeting & 0.00 & 0.04 & 0.03 & 0.06 \\
\hline 2000-2017: Inflation targeting & 0.23 & 0.25 & 0.26 & 0.43 \\
\hline
\end{tabular}

The table shows the average posterior probability that the nominal trend is in line with today's definition of nominal stability $\left(P\left[\underline{\tau}<\tau_{t}<\bar{\tau} \mid \mathbf{y}\right]\right)$, and the probability of under- and overshooting the definition of nominal stability. This definition differs among the various indicators. For CPI inflation, the official target range amounts to $[0 \%, 2 \%]$, whereas, for the other indicators, no official target ranges exist. To account for the fact that the indicators have different trend growth rates, the CPI target range is adapted by subtracting the average growth rate of the CPI and adding the average growth rate of the various indicators. To obtain a stability range that would be applied in practice, the numbers are rounded to half a percentage point for the WPI $([-0.5 \%, 1.5 \%])$, the GDP deflator ([0\%, $2 \%])$, and nominal GDP ([2.5\%, $4.5 \%])$. For nominal GDP, this implies an average $2.5 \%$ productivity growth trend over the entire sample period

are associated with a higher probability of deflation. But also, flexible inflation targeting exhibits a probability of $23 \%$ that inflation is too low 27 .

The other indicators confirm the results at least qualitatively. One issue with applying a definition of nominal stability to the other indicators is that the WPI and nominal GDP exhibit different trend growth rates. I therefore adapt the target range subtracting average CPI inflation from the target range and adding the average growth rate of the other indicators. This lowers the definition of price stability by $0.5 \mathrm{pp}$ for the WPI and increases the stability range by $2.5 \mathrm{pp}$ for nominal GDP growth. The underlying assumption is that all the nominal indicators share a common average inflation rate. However, they have different average growth rates because of different relative price movements and productivity trends ${ }^{28}$. The highest probability of nominal stability we always observe under inflation targeting. In addition, the metal currency regimes are associated with a higher probability of undershooting the range, whereas the probability of surpassing the range is elevated under monetary targeting. One advantage of looking at nominal GDP growth is that it takes into account that falling prices may be desirable if productivity growth is elevated. According to this measure, the probability of stability is only $53 \%$ under inflation targeting, not much higher than under the Gold Standard. As we might expect, the Gold Standard performs relatively better if we use nominal GDP growth because we implicitly assume that productivity-driven deflations are less harmful. By contrast, flexible inflation targeting performs relatively worse because the low inflation rate was not related to advances in productivity.

This descriptive analysis cannot establish a direction of causation from adopting a new monetary regime to nominal stability. For example, inflation targeting may cause a low and stable inflation trend, or inflation targeting may have been adopted because inflation was low in the first place. Bordo and Siklos (2018) suggest that small open economies were likely to change the policy regime in response to changing economic conditions. Although it is beyond the scope of this paper to answer this question definitively, Figure 3 provides the posterior probability of nominal stability to assess the timing relative to the monetary regimes in place. The dark grey areas give the probabilities of overshooting and undershooting. The area in between gives the probability of nominal stability.

For brevity, I focus on the results for CPI inflation. The figures show some interesting variation during the various monetary regimes. The first half of the Bretton Woods regime was associated with a relatively high probability of nominal stability. Only during the second half, when most capital controls were lifted and the USA conducted an expansionary monetary policy, do we see a strong increase in the probability of overshooting. In addition, the probability of nominal stability increased already before flexible inflation targeting was officially introduced. This confirms that the new regime was not the cause of the decline in inflation. Rather, the SNB exploited a good moment to announce an explicit inflation target range. Finally, the probability of undershooting the price stability range rose considerably in recent years. The decline coincides with the GFC, and in 2017, the probability of an inflation trend that is too low amounts to $70 \%$. Of course, the estimates at the end of the sample have to be interpreted with caution because future data points will change the assessment of this period. 

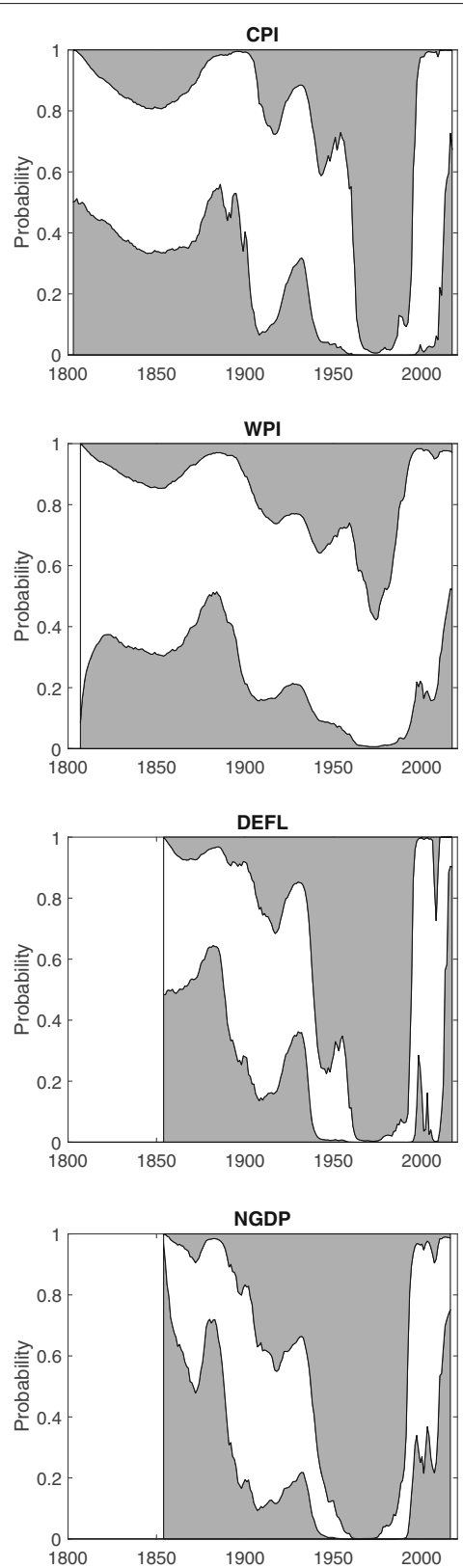

Fig. 3 Probability of nominal stability. The grey areas show the posterior probability that the nominal trend is above or below of today's definition of nominal stability $\left(P\left[\underline{\tau}<\tau_{t}<\bar{\tau} \mid \mathbf{y}\right]\right)$. The area in between gives the probability of nominal stability. This definition differs among the various indicators. For CPI inflation, the official target range amounts to $[0 \%, 2 \%]$, whereas, for the other indicators, no official target ranges exist. To account for the fact that the indicators have different trend growth rates, the CPI target range is adapted by subtracting the average growth rate of the $\mathrm{CPI}$ and adding the average growth rate of the various indicators. To obtain a stability range that would be applied in practice, the numbers are rounded to half a percentage point for the WPI $([-0.5 \%, 1.5 \%])$, the GDP deflator ([0\%, 2\%]), and nominal GDP ([2.5\%, 4.5\%])
The analysis has shown that flexible inflation targeting was successful in its main objective: keeping inflation low and stable. However, the analysis also shows that the inflation trend is lower than under most other fiat currency regimes over the past two centuries. The remainder of this section therefore discusses the implications of the SNB's current low inflation target for the level of nominal interest rates.

Figure 4 gives the yield on government bonds jointly with the estimated permanent component for the CPI and GDP deflator. The bond yield fell by about 7.5pp between 1974 and 2017. According to the estimated CPI trend, more than half can be attributed to lower inflation. According to the GDP deflator, even more of the decline in nominal interest rates can be attributed to lower inflation. The lower panels give the corresponding ex-post real interest rates ${ }^{29}$. Today's real interest rates are in line with most of the after-war period. Only during the late 1990s do we observe a brief increase before the decline starting in the year 2000. Note that there are other reasons than a lower inflation rate why interest rates decline (see, e.g., Bean et al. (2015)). Recent studies emphasized demographic factors, declines in productivity growth, and also a high propensity to save in emerging economies. In addition, Kugler and Weder di Mauro (2002) and Baltensperger and Kugler (2016) emphasize that low interest rates in Switzerland can be traced back to the safe economic and political environment. The estimates show, however, that for Switzerland a relevant part of the decline in nominal interest rates can be attributed to the trend decline in inflation rather than real factors.

\section{Concluding remarks}

This paper assesses nominal stability with a long historical data set and compares the performance of Swiss monetary regimes over the last two centuries.

On the one hand, the analysis reveals that flexible inflation targeting was associated with a historically stable monetary environment. On the other hand, assessing the monetary environment for the nineteenth century is hampered by substantial estimation uncertainty. Although it is possible that the metal currency regimes were associated with a stable monetary environment, the available data do not allow to reach this conclusion with much confidence. This is in line with the finding by Cogley and Sargent (2015) for the USA that the price level was in fact more predictable during post-WW2 fiat currency regimes.

The favorable assessment of the current policy regime comes a caveat. The historical review suggests that monetary regimes were often adapted in response to recent crises and unsustainable monetary arrangements (see also Bordo and Siklos (2018)). For example, the Latin Monetary Union was the response to undesirable melting of silver coins with a high fineness; the Bretton Woods 

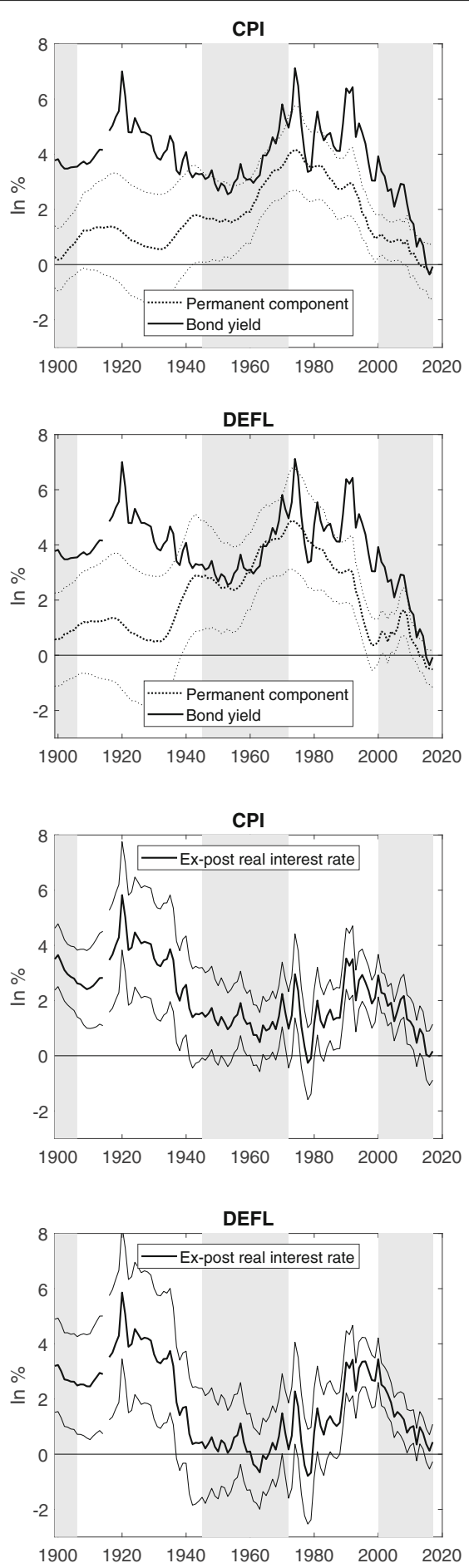

Fig. 4 Bond yields and real interest rates. The solid lines in the first and second panels show a spliced measure of government bond yields (maturity between 5 and 10 years). The dashed lines show the estimated permanent component (mean, 5th percentile, 95th percentile). The third and fourth panels show the implied ex-post real interest rate (mean, 5th percentile, 95th percentile). The shaded areas highlight changes in monetary regimes
System was heavily influenced by the Great Depression and the Gold Standard; monetary and inflation targeting were the answer to bring runaway inflation of the 1970s and 1980s under control. Against this backdrop flexible inflation targeting is unlikely the optimal monetary regime under all circumstances. Indeed, the recent GFC raised questions whether the flexible inflation targeting regime is still appropriate.

The first question concerns the importance of financial conditions in the central bank's mandate. First, under inflation, targeting financial stability is a clearly subordinated goal; it plays a role only to the extent that financial conditions affect future inflation and output. As such, the GFC revealed that central banks should improve their understanding of why financial crises emerge and how financial conditions affect inflation and output fluctuations. Proponents of inflation targeting, however, do not see a need to adapt the monetary regime as such (see, e.g., Svensson (2010)).

Others argue that the focus on inflation stability led central banks to keep interest rates too low for too long in the run up to the GFC. Therefore, flexible inflation targeting, they argue, contributed to the crisis because financial conditions played a subordinated role in the central bank's mandate. In fact, many central banks have been given additional responsibility and instruments aimed at stabilizing financial conditions (see, e.g., Bordo and Siklos (2018)). For example, the Swiss National Bank (2014) can propose to adopt a counter-cyclical capital buffer to the Federal Council in case of excessive credit growth. Increasing the importance of financial stability, however, may introduce a conflict of goals ${ }^{30}$. How these new instruments and responsibilities will affect the weight given to each goal, as well as the monetary transmission mechanism remains to be seen.

The second question concerns the implementation of monetary policy in a low-inflation environment. Because trend inflation has fallen to a historically low level, nominal interest rates are low as well. This limits conventional monetary policy actions because of the effective lower bound on short-term interest rates. Under the current monetary arrangement, nominal short-term interest rates cannot fall substantially below zero. A low inflation target therefore constrains the monetary policy response during recessions. The SNB primarily justifies its low inflation target by a measurement bias in CPI data. However, other central banks usually have adopted a higher inflation target because they take into account not only measurement issues but also the effective lower bound, as well as asymmetries in wage setting.

An implication of the findings of this paper is that complementary monetary policy instruments, such as exchange rate interventions or negative interest on reserves, will likely belong to the standard toolkit in the years to come. Besides factors over which the central 
bank has little control, the SNB's low inflation target is an additional reason why non-conventional monetary policy measures became necessary. An open question worth investigating therefore is whether alternative definitions of nominal stability, for example a higher inflation target range, a price-level target, or a nominal GDP target, would facilitate the conduct of Swiss monetary policy.

\section{Endnotes}

${ }^{1}$ This historical review is based on other authors' more detailed work: see Willis (1901) for the history of the Latin Monetary Union, Flandreau (2004) for a detailed account of Bimetallism in France, Baltensperger (2012) and Baltensperger and Kugler (2017) for Swiss monetary regimes from 1805 to modern times, Swiss National Bank (2007b) for the history of the SNB from 1907 to 2007, Zurlinden (2003) for Switzerland during the Great Depression, Jordan et al. (2010) for the SNB's new monetary policy strategy from 2000 to 2010, Maissen (2015) for an overview of Swiss history since the thirteenth century, Eichengreen (2008) for the global monetary system, and Bernholz (2003) for a general assessment of various monetary regimes and their implications for inflation.

${ }^{2}$ Baltensperger and Kugler (2017) recently published an English version that goes beyond Baltensperger (2012).

${ }^{3}$ I thank Peter Bernholz for bringing this fact to my attention.

${ }^{4}$ It is noteworthy, however, that no Swiss gold coins have been minted until well after Bimetallism has been abandoned (see HSSO (2015) Table O1a).

${ }^{5}$ The literature does not fully agree why silver or bimetallic standards were replaced by the Gold Standard. Some authors argue that the bimetallic system tended to be unstable since changes in the relative price of silver and gold tended to drive one of the two currencies out of circulation. Eichengreen (2008), however, emphasizes that network externalities may have been a major force pushing countries towards adopting uniformly the Gold Standard. Flandreau (2004) dismisses these explanations and suggests that Bimetallism was abandoned because of the Franco-German rivalry, rather than because of an inherent instability or an irresistible attraction of the Gold Standard.

${ }^{6}$ Switzerland belonged to the so-called gold bloc of countries that stuck to the Gold Standard for longer and therefore suffered more (see Eichengreen and Sachs (1985)).

${ }^{7}$ By contrast, Germany and the Netherlands revalued their currencies in 1961.
${ }^{8}$ Although the SNB aimed to dampen the necessary expans ion of the money stock through inward exchange controls and administrative limits to lending (Bernholz (2007) p. 147).

${ }^{9}$ However, this move was not entirely voluntary. This is also reflected in the fact that, after the collapse of the Bretton Woods System, Switzerland applied to join other European countries in a system of managed exchange rates, the so-called currency snake. However, the application was vetoed by France in 1975 (Bernholz (2007), p. 170-172).

${ }^{10}$ Two causes usually referred to are the introduction of the Swiss Interbank Clearing (SIC) system and changes in liquidity provision regulation in the late 1980 s, both reducing demand for base money.

${ }^{11}$ I call the framework "flexible" inflation targeting because (Jordan et al. 2010) point out that: "In general, [the SNB's] monetary policy strategy appears to be more moderate and flexible than the [inflation targeting] model." Their definition is related, but not identical, to the definition by Svensson (1997): "Flexible inflation targeting is when the central bank is to some extent also concerned about other things, for instance, the stability of interest rates, exchange rates, output and employment."

${ }^{12}$ There is some uncertainty regarding the size of this bias. The Boskin Commission (1996) estimate a bias of about 0.8pp for the USA. For Switzerland the bias amounts to 0.5-0.6pp (Brachinger et al. 2000). However, the SFSO has improved CPI measurement in Switzerland over the last 15 years increasingly taking quality changes into account (see, e.g., SFSO (2011)). But also, recent research for the USA by (Goolsbee and Klenow 2018) suggests that the bias stemming from newly introduced products that are not yet incorporated in the CPI tends to be larger than what the (Boskin Commission 1996) suggests.

${ }^{13}$ Less well-known unconventional measures include a purchase program of covered and non-bank corporate bonds from the markets between 2009 and 2010 (see Kettemann and Krogstrup (2014)), and several increases of bank's sight deposits in August 2011 (see Christensen and Krogstrup (2018)).

${ }^{14}$ Productivity changes are a major argument for adopting a NGDP target (see, e.g., Sumner (2014)). Stabilizing NGDP accounts for the fact that prices may fluctuate in response to productivity shocks but a central bank may not want to respond to these shocks. In other words, if positive productivity shocks lead to lower prices and higher real GDP, nominal GDP remains unchanged. By 
contrast, if a deflationary episode occurs because of a restrictive monetary policy stance rather than a positive supply shock nominal GDP declines.

${ }^{15} \mathrm{~A}$ similar argument can be made to look at the stability of nominal wages. Moreover, Erceg et al. (2000) show that, if nominal wages are less regularly adjusted than consumer prices, a central bank optimally puts more weight on stabilizing wage inflation.

${ }^{16}$ All data and codes are available upon request and on www.dankaufmann.com.

${ }^{17}$ I examined the correlation between the inflation rates of the CPI and WPI measure from SFSO (2015d). Indeed, they are almost identical during this period.

${ }^{18}$ See http:Idata.snb.ch, interest rates, yields and foreign exchange market.

${ }^{19}$ This strategy follows (Kugler 2017). Using other series published by the (Swiss National Bank 2007a) yields qualitatively similar results.

${ }^{20} \mathrm{We}$ could also use a multivariate model to estimate real productivity and inflation trends. This would allow to estimate periods of deflation during metal currency regimes that were driven by productivity advances. However, as Sumner (2014) emphasizes, a nominal GDP target does not require to estimate unobserved productivity advances. The reason is that nominal GDP growth remains approximately stable because productivity advances increase real GDP growth but push down inflation. As a consequence, the central bank does not respond to productivity driven deflations that may be less harmful (see, e.g., Beckworth (2007)). Therefore, I prefer to estimate a single trend for nominal GDP growth to assess its overall stability.

${ }^{21}$ Under a price-level targeting regime, we would theoretically expect the price level to be stationary after removing a linear trend (see, e.g., Svensson (2010)). In the empirical specification, I assume that inflation is stationary after removing a stochastic trend.

${ }^{22}$ This may be particularly relevant for Switzerland because Studer and Schuppli (2008) provide an index for almost the entire nineteenth century. Therefore, we would assume anyway that the persistence and variance of the measurement error process is constant during the nineteenth century.

${ }^{23}$ The interest reader is referred to Chan (2013). The estimates are based on adapted versions of his codes. All errors are of course my own.

${ }^{24}$ Note that, if we attach the same prior to both model variants, we can calculate the posterior model probability of the MA specification as $P\left(M_{1} \mid \mathbf{y}\right)=B F /(1+B F)$, where $M_{1}$ stands for the model with the MA component and $B F$ for the Bayes factor (see Koop (2003) p. 4-5). Even for the lowest Bayes factor in the table, the posterior model probability of the MA specification amounts to 0.9 .

${ }^{25}$ Friedman (1968) discusses monetary aggregates, exchange rates, and the price level as guides of monetary stability and argues: "Of the three guides listed, the price level is clearly the most important in its own right. Other things the same, it would be much the best of the alternatives [...]".

${ }^{26}$ Cogley and Sargent (2015) calculate the probability that the price level declines over the next 5 years. In doing so, they include both the permanent and transitory component. Because I cannot disentangle measurement errors from actual movements in the transitory component, this approach is not applicable for Switzerland. In addition, focusing on the long-term trend is more closely related to the SNB's definition of price stability that emphasizes that inflation has to remain in that range only in the medium term.

${ }^{27}$ For CPI inflation, Bordo and Filardo (2005) report a frequency of deflationary episodes of 36\% between 1880 and WW1, 15\% between 1950 and 1969 and 0\% until 2002 for Switzerland. Their exercise differs as they examine the frequency of CPI deflation, whereas, I examine the probability that trend inflation is below of the SNB's definition of nominal stability.

${ }^{28}$ For nominal GDP growth, the range is at the lower end of what Sumner (2014) proposes for the USA. The reason is that the SNB's inflation target as well as productivity growth is lower than in the USA. But the main results are robust to variations in this assumption.

${ }^{29}$ Real interest rates are calculated as the nominal interest rates minus the posterior draws of the permanent component. The permanent component corresponds to the best long-run forecast of inflation. The real interest rate is still an ex-post measure, however, because the estimates are based on past and future data.

${ }^{30}$ Svensson (2010) provides an illustration what could have happened if the US central bank had tried to counter the housing market bubble to avoid the GFC.

\section{Appendix 1}

\section{Priors and convergence of sampler}

The prior specification follows Chan (2013). For the MA coefficient, I assume a truncated normal prior $\psi \sim$ $N\left(\psi_{0}, V_{\psi}\right) \mathbf{1}_{\{|\psi|<1\}}$ with $\psi_{0}=0$ and $V_{\psi}=1$. The 


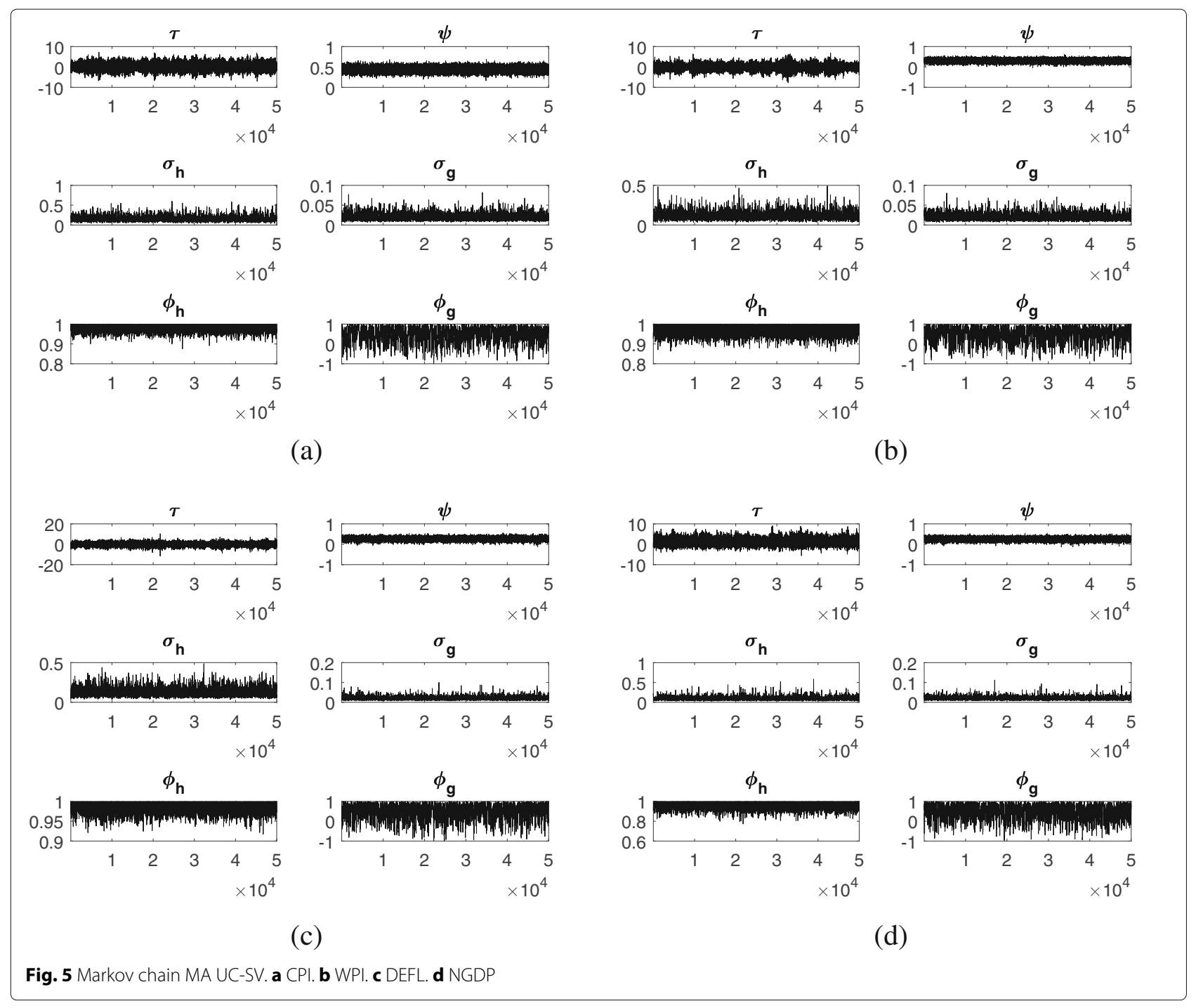




$$
1111
$$


truncation ensures that the MA process is invertible and the model is identified. For the variance of the stochastic volatility equation, I assume independent inverse-gamma priors $\sigma_{i}^{2} \sim I G\left(v_{i}, S_{i}\right), i \in\{g, h\}$ with $v_{g}=v_{h}=10$ and $S_{g}=0.18, S_{h}=0.45$. This implies a prior view that the variance of the transitory shocks changes more than the variance of the permanent shocks. For the stochastic volatility equation, I assume (truncated) normal priors with $\mu_{i} \sim N\left(\mu_{i 0}, V_{\mu i}\right)$ and $\phi_{i} \sim N\left(\phi_{i 0}, V_{\phi i}\right) \mathbf{1}_{\left\{\left|\phi_{i}\right|<1\right\}}$ where I put a relatively strong prior on a persistent stochastic volatility equation: $\mu_{g 0}=\mu_{h 0}=0, V_{\mu g}=V_{\mu h}=$ $5, \phi_{g 0}=\phi_{h 0}=0.9, V_{\phi g}=V_{\phi h}=0.2$.

Figure 5 shows the Markov chain of 50,000 draws, after discarding the first 100,000 draws, for some key parameters for the baseline specification. The chains appear to be stationary and display no breaks or jumps.

Figure 6 shows that the posterior distribution for $\sigma_{g}^{2}$ is almost identical with the prior in the baseline specification. In a robustness test, I therefore set $S_{g}=S_{h}=0.45$ and make the prior for the autoregressive parameters in the stochastic volatility equations less informative with $V_{\phi g}=V_{\phi h}=1$. All main results remain intact.

\section{Appendix 2}

\section{Robustness}

I conducted various robustness tests. First, I varied the prior assumptions for the autoregressive parameter and variance in the stochastic volatility equation of the permanent component (see Table 4). I applied a less informative prior for the autoregressive parameter and increased the prior mean for the variance. The results are qualitatively identical.

Second, I examined whether the persistence of the transitory changes over time for CPI inflation by estimating the model on subsamples (see Table 5). Recall that the transitory component is likely driven by measurement error during the nineteenth century, but by an inflation gap when modern data became available. Despite the different underlying sources, the transitory component is persistent during the nineteenth century as well as thereafter. Although the point estimate of the MA parameter is smaller for the nineteenth century, the probability that it is positive is large. Therefore, allowing for the persistence to vary for historical and modern data is unlikely to change the main conclusions.

Third, I lowered the definition of price stability by $1 \mathrm{pp}$ for all indicators (see Table 6). Recall that the SNB justifies the positive range by measurement error due to quality changes (see Swiss National Bank (2015)). In the absence of such measurement issues, one may argue that the SNB would target an inflation rate in a symmetric range close to $0 \%$. Because mismeasured quality changes may be a more serious issue in an industrialized or service economy, using today's range of nominal stability
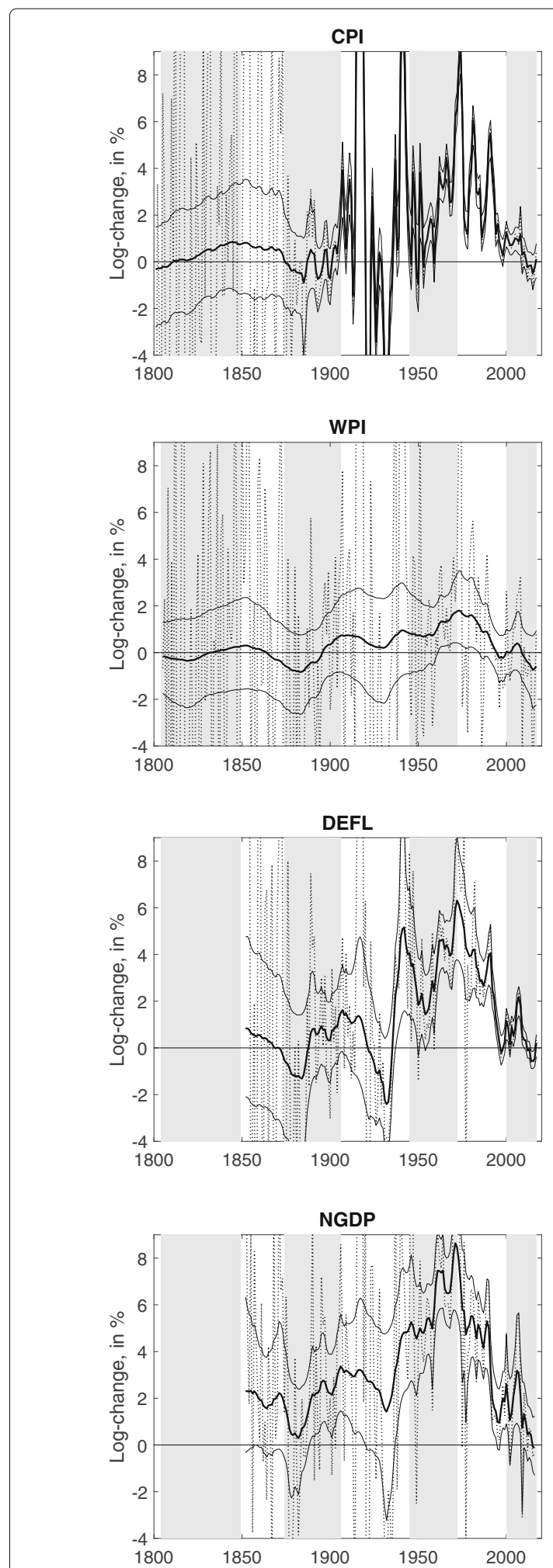

Fig. 7 Permanent component (UC-SV model). UC-SV model without MA component by Stock and Watson (2007). Estimated permanent component (mean, 5th percentile, 95th percentile) and actual data (dashed line). The shaded and unshaded areas represent various monetary regimes 
Table 4 Probability of nominal stability (with alternative prior)

\begin{tabular}{|c|c|c|c|c|}
\hline & $\mathrm{CPI}$ & WPI & DEFL & NGDP \\
\hline \multicolumn{5}{|l|}{ (a) Nominal stability: $P\left[\underline{\tau}<\tau_{t}<\bar{\tau} \mid \mathbf{y}\right]$} \\
\hline 1804-1849: Competing currencies & 0.46 & 0.65 & & \\
\hline 1850-1873: Bimetallism & 0.48 & 0.60 & 0.43 & 0.31 \\
\hline 1874-1906: Gold Standard & 0.53 & 0.62 & 0.49 & 0.49 \\
\hline 1907-1944: World War period & 0.59 & 0.64 & 0.49 & 0.43 \\
\hline 1945-1973: Bretton Woods & 0.40 & 0.65 & 0.15 & 0.04 \\
\hline 1974-1999: Monetary targeting & 0.20 & 0.72 & 0.21 & 0.27 \\
\hline 2000-2017: Inflation targeting & 0.75 & 0.73 & 0.70 & 0.53 \\
\hline \multicolumn{5}{|l|}{ (b) Overshooting: $P\left[\tau_{t}>\bar{\tau} \mid \mathbf{y}\right]$} \\
\hline 1804-1849: Competing currencies & 0.14 & 0.07 & & \\
\hline 1850-1873: Bimetallism & 0.18 & 0.09 & 0.06 & 0.04 \\
\hline 1874-1906: Gold Standard & 0.03 & 0.05 & 0.08 & 0.11 \\
\hline 1907-1944: World War period & 0.23 & 0.22 & 0.31 & 0.45 \\
\hline 1945-1973: Bretton Woods & 0.58 & 0.31 & 0.85 & 0.96 \\
\hline 1974-1999: Monetary targeting & 0.79 & 0.24 & 0.77 & 0.68 \\
\hline 2000-2017: Inflation targeting & 0.01 & 0.02 & 0.04 & 0.03 \\
\hline \multicolumn{5}{|l|}{ (c) Undershooting: $P\left[\tau_{t}<\underline{\tau} \mid \mathbf{y}\right]$} \\
\hline 1804-1849: Competing currencies & 0.41 & 0.28 & & \\
\hline 1850-1873: Bimetallism & 0.34 & 0.31 & 0.51 & 0.65 \\
\hline 1874-1906: Gold Standard & 0.44 & 0.33 & 0.44 & 0.41 \\
\hline 1907-1944: World War period & 0.18 & 0.15 & 0.20 & 0.12 \\
\hline 1945-1973: Bretton Woods & 0.02 & 0.04 & 0.00 & 0.00 \\
\hline 1974-1999: Monetary targeting & 0.00 & 0.04 & 0.03 & 0.06 \\
\hline 2000-2017: Inflation targeting & 0.24 & 0.25 & 0.26 & 0.43 \\
\hline \multicolumn{5}{|c|}{$\begin{array}{l}\text { Results based on an alternative prior specification discussed in the Appendix. The } \\
\text { table shows the average posterior probability that the nominal trend is in line with } \\
\text { today's definition of nominal stability }(P[\underline{\tau}<\tau<<\bar{\tau} \mid \mathbf{y}]) \text {, and the probability of } \\
\text { under- and overshooting the definition of nominal stability. This definition differs } \\
\text { among the various indicators. For CPI inflation, the official target range amounts to } \\
{[0 \%, 2 \%] \text {, whereas, for the other indicators, no official target ranges exist. To account }} \\
\text { for the fact that the indicators have different trend growth rates, the CPI target } \\
\text { range is adapted by subtracting the average growth rate of the CPI and adding the } \\
\text { average growth rate of the various indicators. To obtain a stability range that would } \\
\text { be applied in practice, the numbers are rounded to half a percentage point for the } \\
\text { WPI ([- } 0.5 \%, 1.5 \%]) \text {, the GDP deflator ([0\%, } 2 \%]) \text { and nominal GDP ([2.5\%, } 4.5 \%])\end{array}$} \\
\hline
\end{tabular}

Table 5 Posterior moments $\psi$ for CPI inflation

\begin{tabular}{llll}
\hline & $1800-2017$ & $1800-1907$ & $1907-2017$ \\
\hline$E[\psi \mid \mathbf{y}]$ & 0.44 & 0.28 & 0.63 \\
$\sqrt{\operatorname{var}[\psi \mid \mathbf{y}]}$ & 0.06 & 0.10 & 0.10 \\
$P[\psi>0 \mid \mathbf{y}]$ & 1.00 & 0.99 & 1.00 \\
\hline
\end{tabular}

Posterior moments of the MA parameter $\psi$. The table gives the posterior mean, standard deviation, and the posterior probability that the coefficient is larger than zero
Table 6 Probability of nominal stability (with alternative definition of nominal stability)

\begin{tabular}{lcccc}
\hline & CPI & WPI & DEFL & NGDP \\
\hline \multicolumn{1}{l}{ (a) Nominal stability: $P\left[\underline{\tau}<\tau_{t}<\bar{\tau} \mid \mathbf{y}\right]$} & & & \\
1804-1849: Competing currencies & 0.52 & 0.66 & & \\
1850-1873: Bimetallism & 0.47 & 0.59 & 0.60 & 0.54 \\
1874-1906: Gold Standard & 0.70 & 0.64 & 0.53 & 0.52 \\
1907-1944: World War period & 0.40 & 0.42 & 0.36 & 0.26 \\
1945-1973: Bretton Woods & 0.13 & 0.24 & 0.03 & 0.01 \\
1974-1999: Monetary targeting & 0.06 & 0.34 & 0.12 & 0.17 \\
2000-2017: Inflation targeting & 0.72 & 0.70 & 0.71 & 0.66
\end{tabular}

(b) Overshooting: $P\left[\tau_{t}>\bar{\tau} \mid \mathbf{y}\right]$

1804-1849: Competing currencies $\quad 0.32 \quad 0.27$

1850-1873: Bimetallism $\quad 0.39-0.32$

$\begin{array}{lll}0.32 & 0.19-0.13\end{array}$

1874-1906: Gold Standard $\quad \begin{array}{lllll}0.18 & 0.27 & 0.27 & 0.31\end{array}$

1907-1944: World War period $\quad \begin{array}{lllll}0.55 & 0.55 & 0.57 & 0.70\end{array}$

1945-1973: Bretton Woods $\quad 0.87 \quad 0.75 \quad 0.97 \quad 0.99$

1974-1999: Monetary targeting $\quad \begin{array}{lllll}0.94 & 0.66 & 0.88 & 0.82\end{array}$

2000-2017: Inflation targeting $\quad \begin{array}{lllll}0.25 & 0.25 & 0.27 & 0.20\end{array}$

(c) Undershooting: $P\left[\tau_{t}<\underline{\tau} \mid \mathbf{y}\right]$

1804-1849: Competing currencies $0.16 \quad 0.07$

1850-1873: Bimetallism $\quad 0.14 \quad 0.09 \quad 0.21 \quad 0.33$

1874-1906: Gold Standard $\quad \begin{array}{lllll}0.12 & 0.09 & 0.20 & 0.18\end{array}$

1907-1944: World War period $\quad \begin{array}{lllll}0.05 & 0.03 & 0.07 & 0.04\end{array}$

1945-1973: Bretton Woods $\quad 0.00 \quad 0.00 \quad 0.00 \quad 0.00$

1974-1999: Monetary targeting $\quad \begin{array}{lllll}0.00 & 0.00 & 0.00 & 0.01\end{array}$

2000-2017: Inflation targeting $\quad 0.02 \quad 0.04 \quad 0.01 \quad 0.14$

The table shows the average posterior probability that the nominal trend is in line with an alternative definition of nominal stability $\left(P\left[\underline{\tau}<\tau_{t}<\bar{\tau} \mid \mathbf{y}\right]\right)$, and the probability of under- and overshooting the definition of nominal stability. This definition differs among the various indicators. For CPI inflation, the official target range is lowered to $[-1 \%, 1 \%]$, whereas, for the other indicators, no official target ranges exist. To account for the fact that the indicators have different trend growth rates, the CPI target range is adapted by subtracting the average growth rate of the $\mathrm{CPl}$ and adding the average growth rate of the various indicators. To obtain a stability range that would be applied in practice, the numbers are rounded to half a percentage point for the WPI $([-1.5 \%, 0.5 \%])$, the GDP deflator $([-1 \%, 1 \%])$, and nominal GDP ([1.5\%, 3.5\%])

may distort the analysis. With the alternative definition of nominal stability the Gold Standard performs somewhat better. Overall, however, the current monetary regime still provides the highest probability of nominal stability.

Fourth, I also estimate the UC-SV model by Stock and Watson (2007). As we would expect, more of the variation in the data is therefore attributed to the permanent component and the trends become more volatile as a result (see Table 7). The main result that trend inflation was historically low under flexible inflation targeting remains intact.

Fifth, I estimated the ex-post real interest rates with quarterly data on a shorter sample (see Fig. 8). The quarterly estimates starting in 1960 confirm that the ex-post real interest rate is currently at a level observed regularly from 1960 to 1980 . 

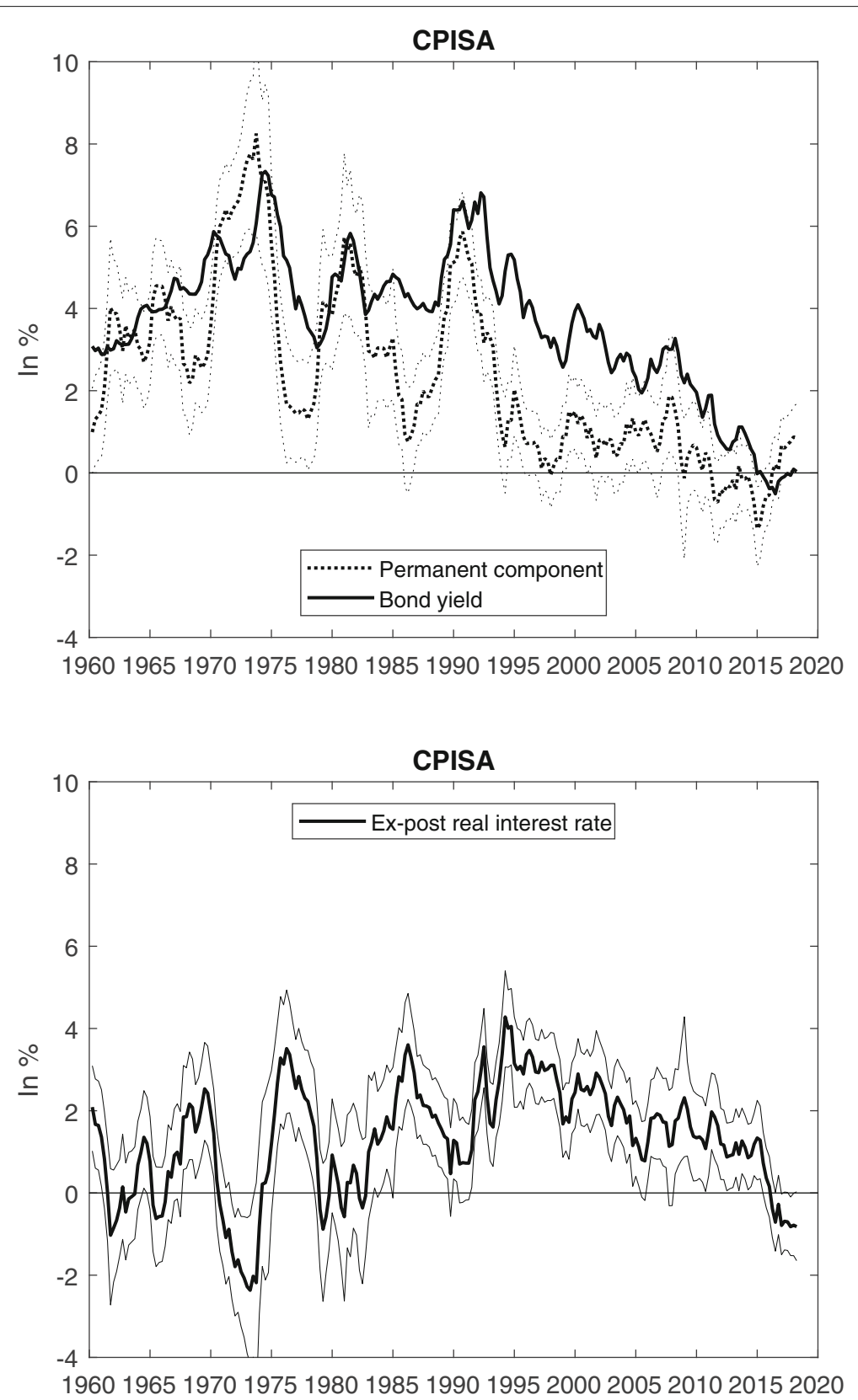

Fig. 8 Trend decline in bond yields and real interest rate (quarterly data). The solid lines in the left panel shows a quarterly measure of 10-year government bond yields. The dashed lines show the estimated permanent component of CPI inflation (mean, 5th percentile, 95th percentile). The right panel shows the implied ex-post real interest rate. The data stem from the OECD and were seasonally adjusted using TRAMO-SEATS via www. seasonal.website 
Table 7 Probability of nominal stability (UC-SV model)

\begin{tabular}{lcccc}
\hline & CPI & WPI & DEFL & NGDP \\
\hline $\begin{array}{l}\text { (a) Nominal stability: } P\left[\underline{\tau}<\tau_{t}<\bar{\tau} \mid \mathbf{y}\right] \\
\text { 1804-1849: Competing currencies }\end{array}$ & 0.51 & 0.60 & & \\
1850-1873: Bimetallism & 0.52 & 0.60 & 0.40 & 0.45 \\
1874-1906: Gold Standard & 0.44 & 0.57 & 0.49 & 0.48 \\
1907-1944: World War period & 0.21 & 0.62 & 0.33 & 0.42 \\
1945-1973: Bretton Woods & 0.31 & 0.67 & 0.20 & 0.05 \\
1974-1999: Monetary targeting & 0.40 & 0.67 & 0.19 & 0.22 \\
2000-2017: Inflation targeting & 0.72 & 0.68 & 0.63 & 0.37 \\
(b) Overshooting: $P\left[\tau_{t}>\bar{\tau} \mid \mathbf{y}\right]$ & & & & \\
1804-1849: Competing currencies & 0.10 & 0.07 & & \\
1850-1873: Bimetallism & 0.14 & 0.09 & 0.17 & 0.15 \\
1874-1906: Gold Standard & 0.04 & 0.05 & 0.08 & 0.11 \\
1907-1944: World War period & 0.42 & 0.21 & 0.29 & 0.39 \\
1945-1973: Bretton Woods & 0.55 & 0.29 & 0.79 & 0.94 \\
1974-1999: Monetary targeting & 0.59 & 0.26 & 0.74 & 0.63 \\
2000-2017: Inflation targeting & 0.01 & 0.02 & 0.09 & 0.08 \\
(c) Undershooting: $P\left[\tau_{t}<\underline{\tau} \mid \mathbf{y}\right]$ & & & & \\
1804-1849: Competing currencies & 0.39 & 0.33 & & \\
1850-1873: Bimetallism & 0.34 & 0.32 & 0.44 & 0.39 \\
1874-1906: Gold Standard & 0.52 & 0.39 & 0.43 & 0.42 \\
1907-1944: World War period & 0.37 & 0.17 & 0.38 & 0.19 \\
1945-1973: Bretton Woods & 0.14 & 0.04 & 0.01 & 0.00 \\
1974-1999: Monetary targeting & 0.01 & 0.07 & 0.07 & 0.15 \\
2000-2017: Inflation targeting & 0.27 & 0.30 & 0.28 & 0.55 \\
\hline
\end{tabular}

UC-SV model without MA component by Stock and Watson (2007). The table shows the average posterior probability that the nominal trend is in line with today's definition of nominal stability $\left(P\left[\underline{\tau}<\tau_{t}<\bar{\tau} \mid \mathbf{y}\right]\right)$, and the probability of under- and overshooting the definition of nominal stability. This definition differs among the various indicators. For CPI inflation, the official target range amounts to [0\%, 2\%], whereas, for the other indicators, no official target ranges exist. To account for the fact that the indicators have different trend growth rates, the CPI target range is adapted by subtracting the average growth rate of the CPI and adding the average growth rate of the various indicators. To obtain a stability range that would be applied in practice, the numbers are rounded to half a percentage point for the WPI $([-0.5 \%, 1.5 \%])$, the GDP deflator $([0 \%, 2 \%])$, and nominal GDP $([2.5 \%, 4.5 \%])$

\section{Abbreviations}

CPI: Consumer price index; DEFL: Deflator; GDP: Gross Domestic Product; GFC: Global financial crisis; HSSO: Historical Statistics of Switzerland Online; i.i.d.: Identically and independently distributed; MA: Moving average; NGDP: Nominal Gross Domestic Product; SECO: State Secretariat for Economic Affairs; SFSO: Swiss Federal Statistical Office; SNB: Swiss National Bank; UC-SV: Unobserved-components stochastic volatility; WPI: Wholesale price index WW1: World War 1; WW2: World War 2

\section{Acknowledgements}

I thank two anonymous referees, the Editor Martin Brown, Ernst Baltensperger, Peter Bernholz, Brad DeLong, Barry Eichengreen, Florian Huber, Markus Knell, Carlos Lenz, Dimitris Korobilis, Klaus Neusser, Samad Sarferaz, Tobias Straumann, Mark Watson, and participants at the ESOBE Annual Conference, the SSES Annual Meeting, the Swiss National Bank Brown Bag Seminar, the KOF Swiss Economic Institute Brown Bag Seminar and the BuBa-OeNB-SNB Workshop, for helpful comments and discussions.

\section{Funding}

Not applicable.

\section{Availability of data and materials}

Data and codes will be available from the author upon request and on www. dankaufmann.com.

\section{Authors' contributions}

The author read and approved the final manuscript.

\section{Authors' information}

The author is assistant professor of applied macroeconomics at the University of Neuchâtel and associated research professor at the KOF Swiss Economic Institute, ETH Zurich.

\section{Competing interests}

The author declares that he has no competing interests.

\section{Publisher's Note}

Springer Nature remains neutral with regard to jurisdictional claims in published maps and institutional affiliations.

Received: 20 July 2018 Accepted: 5 April 2019

Published online: 25 June 2019

\section{References}

Allen, S.G. (1992). Changes in the cyclical sensitivity of wages in the United States, 1891-1987. American Economic Review, 82(1), 122-140.

Ascari, G., \& Sbordone, A.M. (2014). The macroeconomics of trend inflation. Journal of Economic Literature, 52(3), 679-739.

Baltensperger, E. (2007). The National Bank's monetary policy: Evolution of policy framework and policy performance, In The Swiss National Bank 1907-2007 (pp. 569-597). Zürich: Neue Zürcher Zeitung Publishing.

Baltensperger, E. (2012). Der Schweizer Franken - eine Erfolgsgeschichte: Die Währung der Schweiz im 19. und 20. Jahrhundert. Zürich: NZZ Libro.

Baltensperger, E., \& Kugler, P. (2016). The historical origins of the safe haven status of the Swiss franc. Aussenwirtschaft, 67(2), 1-30.

Baltensperger, E., \& Kugler, P. (2017). Swiss monetary history since the early 19th century. Studies in Macroeconomic History. Cambridge: Cambridge University Press. https://doi.org/10.1017/9781108185523.

Bean, C., Broda, C., Ito, T., Kroszner, R. (2015). Low for long? Causes and consequences of persistently low interest rates. Geneva Reports on the World Economy. London: CEPR Press. https://voxeu.org/sites/default/files/ file/Geneva17_28sept.pdf.

Beckworth, D. (2007). The postbellum deflation and its lessons for today. The North American Journal of Economics and Finance, 18(2), 195-214.

Bernanke, B.S. (2003). Remarks by Governor Ben S. Bernanke. Dallas, Texas. www. federalreserve.gov/boarddocs/speeches/2003/20031024/default.htm. Accessed 23 Apr 2019

Bernholz, P. (2003). Monetary regimes and inflation. Cheltenham: Edward Elgar Publishing.

Bernholz, P. (2007). From 1945 to 1982: The transition from inward exchange controls to money supply management under floating exchange rates, (pp. 109-199). Zürich: Neue Zürcher Zeitung Publishing.

Beveridge, S., \& Nelson, C.R. (1981). A new approach to decomposition of economic time series into permanent and transitory components with particular attention to measurement of the 'business cycle'. Journal of Monetary Economics, 7(2), 151-174.

Bordo, M.D., \& Filardo, A. (2005). Deflation and monetary policy in a historical perspective: Remembering the past or being condemned to repeat it? Economic Policy, 20(44), 799-844.

Bordo, M.D., \& James, H. (2007). From 1907 to 1946: A happy childhood or a troubled adolescence? In The Swiss National Bank 1907-2007 (pp. 29-107). Zürich: Neue Zürcher Zeitung Publishing

Bordo, M.D., \& Kydland, F.E. (1996). The Gold Standard as commitment mechanism. In T. Bayoumi, B. Eichengreen, M.P. Taylor (Eds.), Modern Perspectives on the Gold Standard. chap 3 (pp. 55-100). Cambridge: Cambridge University Press.

Bordo, M.D., \& Siklos, P.L. (2018). Central banks: Evolution and innovation in historical perspective. In R. Edvinsson, T. Jacobson, D. Waldenström (Eds.), Sveriges Riksbank and the History of Central Banking. https://doi.org/10.1017/ 9781108140430.002 (pp. 26-89). Cambridge: Cambridge University Press, Studies in Macroeconomic History.

Boskin Commission (1996). Toward a more accurate measure of the cost of living: Final report to the Senate Finance Committee from the Advisory Commission to study the consumer price index. www.ssa.gov/history/ reports/boskinrpt.html. Accessed 23 Apr 2019.

Brachinger, H., Schips B., Stier W. (2000). Expertise zur Relevanz des "Boskin-Reports" für den schweizerischen Landesindex der 
Konsumentenpreise. www.bfs.admin.ch/bfsstatic/dam/assets/1043764/ master. Accessed 23 Apr 2019.

Burdekin, R.C.K., \& Siklos, P.L. (2013) In R.E. Parker \& R. Whaples (Eds.), Gold resumption and the deflation of the 1870s. Routledge: Handbook of Major Events in Economic History.

Chan, J.C. (2013). Moving average stochastic volatility models with application to inflation forecast. Journal of Econometrics, 176(2), 162-172.

Christensen, J.H., \& Krogstrup, S. (2018). Transmission of quantitative easing: The role of central bank reserves. The Economic Journal. https:// onlinelibrary.wiley.com/doi/full/10.1111/ecoj.12600.

Cogley, T., \& Sargent, T.J. (2015). Measuring price-level uncertainty and instability in the United States, 1850-2012. The Review of Economics and Statistics, 97(4), 827-838.

Cogley, T., Primiceri, G.E., Sargent, T.J. (2010). Inflation-gap persistence in the US. American Economic Journal: Macroeconomics, 2(1), 43-69.

Cogley, T., Sargent, T.J., Surico, P. (2015). Price-level uncertainty and stability in the U.K. Journal of Economic Dynamics and Control, 52, 1-16.

D'Agostino, A., \& Surico, P. (2012). A century of inflation forecasts. The Review of Economics and Statistics, 94(4), 1097-1106.

Eichengreen, B. (2008). Globalizing capital: A history of the international monetary system, 2nd edn. Princeton: Princeton University Press.

Eichengreen, B., \& Sachs, J. (1985). Exchange rates and economic recovery in the 1930s. The Journal of Economic History, 45(04), 925-946.

Eichengreen, B., \& Temin, P. (2000). The Gold Standard and the Great Depression. Contemporary European History, 9(2), 183-207.

Erceg, C.J., Henderson, D.W., Levin, A.T. (2000). Optimal monetary policy with staggered wage and price contracts. Journal ofMonetary Economics, 46(2), 281-313.

Flandreau, M. (2004). The glitter of gold: France, Bimetallism, and the emergence of the international Gold Standard, (pp. 1848-1873). Oxford: Oxford University Press.

Frankel, J. (2012a). The death of inflation targeting. Accessed 23 Apr 2019. https://voxeu.org/article/inflation-targeting-dead-long-live-nominalgdp-targeting.

Frankel, J. (2012b). Product price targeting - a new improved way of inflation targeting. Macroeconomic Review. Monetary Authority of Singapore. http:// www.mas.gov.sg/ /media/resource/publications/macro_review/2012/ MRApr12_SF_B.pdf.

Friedman, M. (1968). The role of monetary policy. American Economic Review, 58(1), 1-17.

Goolsbee, A.D., \& Klenow, P.J. (2018). Internet Rising, Prices Falling: Measuring Inflation in a World of E-Commerce. In AEA Papers and Proceedings vol. 108 (pp. 488-92)

Hayek, F.A. (1978). Denationalisation of money - The argument refined, 2nd edn. London: The Intitute of Economic Affairs.

Hoffmann, M., \& Woitek, U. (2011). Emerging from the war: Gold Standard mentality, current accounts and the international business cycle 1885-1939. ECON - Working Papers 057, Department of Economics, University of Zurich.

HSSO (2015). Historical Statistics of Switzerland Online (HSSO). http://www.fsw. uzh.ch/hstat/nls_rev/overview.php. Accessed Jan 2016.

Jordan, T.J. (2009). Die Geldpolitik der Schweizerischen Nationalbank in stürmischen Zeiten. Zurich: Speech at the Geldmarkt-Apero. https://www. snb.ch/de/mmr/speeches/id/ref_20090319_tjn/source/ref_20090319_tjn. de.pdf. Accessed 23 Apr 2019.

Jordan, T.J., \& Peytrignet, M. (2007). The Path to Interest Rate Management and Inflation Forecasts, In The Swiss National Bank 1907-2007 (pp. 255-272). Zürich: Neue Zürcher Zeitung Publishing.

Jordan, T.J., Peytrignet, M., Rossi, E. (2010). Ten years' experience with the Swiss National Bank's monetary policy strategy. Swiss Journal of Economics and Statistics, 146(I), 9-90.

Kaufmann, D. (2017). Is deflation costly after all? The perils of erroneous historical classifications. IRENE Working Papers 17-09, IRENE Institute of Economic Research, University of Neuchâtel.

Kettemann, A., \& Krogstrup, S. (2014). Portfolio balance effects of the Swiss National Bank's bond purchase program. Journal of Macroeconomics, 40(C), 132-149. Koop, G. (2003). Bayesian Econometrics. New York: Wiley.

Kugler, P. (1999). Price level trend-stationarity and the instruments and targets of monetary policy: An empirical note. Economics Letters, 63(1), 97-101.

Kugler, P. (2017). Sinkende Zinsen im Laufe der Geschichte. Die Volkswirtschaft, 5-2017, 6-11.

Kugler, P., \& Weder di Mauro, B. (2002). The puzzle of the Swiss interest rate island: Stylized facts and a new interpretation. Aussenwirtschaft, 57(01), 49-64.

Maissen, T. (2015). Geschichte der Schweiz. Reclam: Ditzingen.
Meade, J.E. (1978). The meaning of "internal balance". The Economic Journal, 88(351), 423-35

Obstfeld, M. (1993) In M.D. Bordo \& B. Eichengreen (Eds.), The adjustment mechanism, (pp. 201-268). Chicago: University of Chicago Press.

Romer, C. (1986a). Is the stabilization of the postwar economy a figment of the data American Economic Review, 76, 314-3347.

Romer, C. (1986b). Spurious volatility in historical unemployment data. Journal of Political Economy, 94(1), 1-37.

Rosenkranz, P., Straumann, T., Woitek, U. (2014). A small open economy in the Great Depression: The case of Switzerland. Working Paper 164, University of Zurich.

SECO (2015). Gross Domestic Product quarterly data. https://www.seco.admin. ch/seco/en/home/wirtschaftslage---wirtschaftspolitik/Wirtschaftslage/ bip-quartalsschaetzungen-.html. Accessed June 2018.

SFSO (2011). Der Landesindex der Konsumentenpreise: Dezember $2010=100$. Methodenübersicht und Gewichtung, 2011. https://www.bfs.admin.ch/ bfsstatic/dam/assets/347838/master. Accessed 23 Apr 2019.

SFSO (2015a). Bevölkerungsstand und -struktur - Detaillierte Daten. https:// www.bfs.admin.ch/bfs/de/home/statistiken/bevoelkerung/standentwicklung/bevoelkerung.html. Accessed June 2018.

SFSO (2015b). Gross Domestic Product (GDP) - Data, indicators. https://www. bfs.admin.ch/bfs/en/home/statistics/national-economy/nationalaccounts/gross-domestic-product.html. Accessed June 2018.

SFSO (2015c). Schweizerische Preisindizes, 1914-2014. https://www.bfs.admin ch/bfs/de/home/statistiken/preise/schweizerische-preisindizes-19142014.html. Accessed June 2016.

SFSO (2015d). Verbraucherpreise. www.bfs.admin.ch/bfs/portal/de/index/ dienstleistungen/history/01/00/05/01.html. Accessed June 2016

Stock, J.H., \& Watson, M.W. (2007). Why has U.S. inflation become harder to forecast? Journal of Money. Credit and Banking, 39(s1), 3-33.

Straumann, T. (2010). Fixed ideas of money: Small states and exchange rate regimes in twentieth-century Europe. Cambridge: Cambridge University Press. https://doi.org/10.1017/CBO9780511750953.

Studer, R., \& Schuppli, P. (2008). Deflating Swiss prices over the past five centuries. Historical Methods, 41(3), 137-153.

Sumner, S. (2014). Nominal GDP targeting: A simple rule to improve Fed performance. Cato Journal, 34(2), 315-337.

Svensson, L.E. (1997). Inflation targeting in an open economy: Strict or flexible inflation targeting?. Reserve Bank of New Zealand Discussion Paper Series G97/8, Reserve Bank of New Zealand.

Svensson, L.E. (2010). Inflation targeting. In B.M. Friedman \& M. Woodford (Eds.), Handbook of Monetary Economics, vol 3. chap 22 (pp. 1237-1302). Amsterdam: Elsevier.

Swiss National Bank (2007a). Interest rates and yields. Historical Time Series, 4. https://www.snb.ch/en/mmr/reference/renditen_book/source/ renditen_book.en.pdf.

Swiss National Bank (2007b). The Swiss National Bank 1907-2007. Zürich: Neue Zürcher Zeitung Publishing.

Swiss National Bank (2009). Quarterly Bulletin 1/2009, Swiss National Bank. https://www.snb.ch/en/mmr/reference/quartbul_2009_1_komplett/ source/quartbul_2009_1_komplett.en.pdf.

Swiss National Bank (2014). Implementing the countercyclical capital buffer in Switzerland: concretising the Swiss National Bank's role. https://www.snb. ch/en/mmr/reference/CCB\%20communication/source/CCB \%20communication.en.pdf. Accessed 23 Apr 2019.

Swiss National Bank (2015). Questions and answers on monetary policy strategy. https://www.snb.ch/en/ifor/public/qas/id/qas_gp_strat\#t9. Accessed 23 Apr 2019.

Willis, H.P. (1901). A history of the Latin Monetary Union. Chicago: University of Chicaco Press.

Zurlinden, M. (2003). Gold Standard, deflation and depression: The Swiss economy during the Great Depression. Quarterly Bulletin 2/2003, Swiss National Bank. https://snb.ch/en/mmr/reference/quartbul_2003_2/ source/quartbul_2003_2.en.pdf. 